【論文】

\title{
不連続面を有する軟岩の力学挙動と破壊規準 \\ MECHANICAL BEHAVIOR AND FAILURE CRITERION OF JOINTED SOFT ROCK
}

\author{
足立 紀 尚*・森 田栄 治** \\ By Toshihisa ADACHI and Eiji MORITA
}

\section{1. 序論}

軟岩といえども対象となるのは, 層理, 節理などの地 質分離面 (不連続面) が内在する岩盤であるため, 不連 続面の力学特性に及ぼす影響を解明する必要がある.そ こで，切断面を与えた円柱供試体（大谷石）を用い三軸 試験を行った先の研究 ${ }^{11}$ 亿おいて, 切断面を有する軟岩 供試体の最大強度, おょび残留強度ともに, $\mathrm{Hobbs}^{2}$, Murrell ${ }^{3)}$ が岩石質材料に対して 提唱しているべき関数 型の破壊規淮式で表わせることを明らかにした.さらに 破壊規準式に含まれる残留強度に対する強度定数は, 切 断面と最大主応力作用面とのなす角に無関係に一定値を とり, 最大強度に対する強度定数は, 切断面の角度の関 数となることを示したが，その関数関係の決定は残され た課題であった.

本研究は上記の課題を解決するため, 泥岩を試料に選 び同様の三軸試験を行った。しかし本研究においては, 先の研究と異なる観点に立って実験結果を検討し, 未解 決の課題を含めて弱面を有する軟岩の破壊挙動を説明で きる新たな破壊規準を提案する.

ここに提案する破壊規準は, 既存の切断面に沿ってす ベり破壊を生じる場合は，切断面に作用する垂直応力 $\sigma^{\prime}$ とせん断応力 $\tau$ との, 他方既存の切断面とは別に新たな 破断面を生ずる場合には，その破断面に作用する $\sigma^{\prime}$ と ことの最大強度時および残留強度時の関係がべき関数型 で与えられることに基づいて誘導した．なお本破壊規準 式に含まれる強度定数は, 不連続面の有無またその角度 に関係せず，対象とする軟岩固有の材料定数として決定 できるものである.

次に 2 つ破壊形態, 寸なわち既存の切断面に沿う破 壊と，新たに破断面を生ずる破壊とのいずれが生ずるか

\footnotetext{
* 正会員 Ph.D. 京都大学助教授 防多研究所

** 学生会員 京都大学大学院
}

に対する条件を求めるため，先に得た破壊規準による 2 本の破壊曲線（最大ならびに残留）と，供試体内の応力 状態を表わすMohr の応力円との関係を用いることによ って, 既存の切断面に沿うすべり破壊が生じる角度の範 囲を, 拘束圧との関係として与えた。

岩盤の強度は, 図 -1に示すようにそ の上限值を岩石の最 大強度に, 下限值を 残留強度にとり,一 般にその範囲内にあ ると考えられる.そ

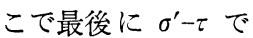
表わされた破壊規準 を, 平均有効応力 $\frac{\sigma_{1}{ }^{\prime}+\sigma^{\prime}{ }_{3}}{2} \sim$ せん断応

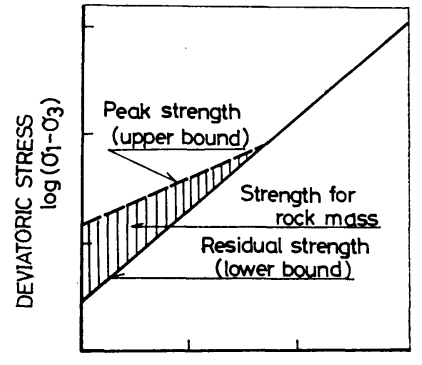

MEAN STRESS $\log \left(\sigma^{\prime} \mathrm{m}\right)$

図一1 岩石の強度と岩盤の強度 力 $\frac{\sigma_{1}-\sigma_{3}}{2}$ 関倸に変換することによって, 図一1 の考え 方の妥当性を検証した.

\section{2. 実験装置，試料ならびに実験方法}

実験装置はすでに報告) したとおりであるが，容量 $200 \mathrm{kgf} / \mathrm{cm}^{2}$ (19.6 MPa) の三軸室を用いた.

試料は第三紀堆積の泥岩で, その物理諸量を表一1に 示す. 供試体は, 直径 5 $\mathrm{cm}$, 高さ $10 \mathrm{~cm}$ の円柱 形であって, 図一2 に示 すように軸荷重（最大主 応力 $\sigma_{1}$ ) 作用面と種々の 角度 $\theta$ をもつ切断面をダ
表一1 物理諸量

\begin{tabular}{c|c|l}
\hline 間 隙 比 & $e$ & 1.40 \\
間 鿣 率 & $n$ & $58.3(\%)$ \\
湿潤密度 & $r t$ & $1.66 \times 10^{3}\left(\mathrm{~kg} / \mathrm{m}^{3}\right)$ \\
乾燥密度 & $r_{d}$ & $1.09 \times 10^{3}\left(\mathrm{~kg} / \mathrm{m}^{3}\right)$ \\
粒子比重 & $G_{s}$ & 2.65
\end{tabular}
イヤモンドカッターにより入れた供試体と切断面のない (intact rock) 供試体を用いた。

なお，水で飽和した軟岩を対象とすることから，供試 
体を容器内に水浸させ, 24 時間以上サクション をかけて脱気を行い飽和 させた。

実験は $1 \mathrm{kgf} / \mathrm{cm}^{2}(9.8$ $\left.\times 10^{-2} \mathrm{MPa}\right)$ のバックプ $\sigma_{3}-$ レッシャーを適用し，所 定の側圧で 24 時間等方 圧密した後，ひずみ制御 による $\left(2.8 \times 10^{-2} \%\right.$ $\left.\min , \quad 4.7 \times 10^{-2} \% / \mathrm{s}\right)$ 排水せん断試験である。 なお，用いた側圧は，

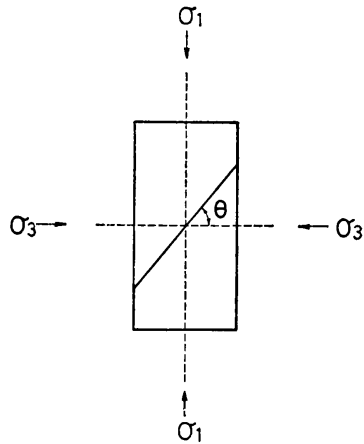

図一2 角度 $\theta$ の切断面を 与えた供試体 $\sigma_{3}{ }^{\prime}=1,3,6,10,20 \mathrm{kgf} / \mathrm{cm}^{2}, 9.8 \times 10^{-2} \mathrm{MPa}$ である.

応力計算における断面補正は，先の報告 ${ }^{1)}$ と同様であ る.ただし，堀卢による断面補正法は，切断面に関係な く新しく破断面が生じた供試体については最大強度到達 点以降で, また既存の切断面に沿ってすべりを生じたも のについては，応力ーひずみ関係において弾性変形から の離脱点を求め，それ以降で適用した。

\section{3. 実験結果と考察}

\section{（1）切断面の角度ならびに拘束圧と破壊形態}

Intact ならびに切断面を有する供試体の試験後の破壊 形態を図一3 に示している. 図中点線は 既存の切断面 を，実線は実際に生じた破断面を意味しているななお既 存の切断面に沿ってすべり破壊を生じた供試体は, 点線 に平行な実線によって表わしているまた図中の記号 CD-1 は $1 \mathrm{kgf} / \mathrm{cm}^{2}\left(9.8 \times 10^{-2} \mathrm{MPa}\right)$ の有効側圧で圧密 排水せん断試験を行ったことを意味しており，ほかもこ れに準ずる．破断面の最大主応力作用面からのなす角 $\theta$ は，表一2 にまとめて示している.
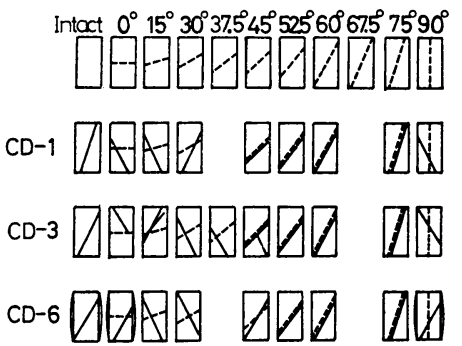

CD-10

QOAOQD

CD-20.

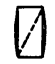

図一3 供試体中に生じた破壊すべり面と既存の切断面
表一2 破断面ならびにすべり面の角度と, 面上に 作用する最大強度時, 残留強度時の応力

\begin{tabular}{|c|c|c|c|c|c|}
\hline & \multirow{2}{*}{\begin{tabular}{|l} 
破断面, \\
すべり面 \\
の角度
\end{tabular}} & \multicolumn{2}{|c|}{$\left(\mathrm{kgf} / \mathrm{cm}^{2}, 9.8 \times 10^{-2} \mathrm{MPa}\right)$} & \multicolumn{2}{|c|}{$\left(\mathrm{kgf} / \mathrm{cm}^{2}, 9.8 \times 10^{-2} \mathrm{MPa}\right)$} \\
\hline & & $\sigma_{P}^{\prime}$ & $\tau_{P}$ & $\sigma_{R^{\prime}}$ & $\tau_{R}$ \\
\hline \multicolumn{6}{|l|}{$\langle C D-1\rangle$} \\
\hline Intact & $74^{\circ}$ & 3.95 & 10.29 & 1.88 & 3.07 \\
\hline $0^{\circ}$ & $63^{\circ}$ & 8.09 & 13.91 & 3.99 & 5.87 \\
\hline $15^{\circ}$ & $66^{\circ}$ & 7.33 & 14.21 & 3.35 & 5.28 \\
\hline $30^{\circ}$ & $74^{\circ}$ & 3.75 & 9.61 & 2.10 & 3.82 \\
\hline $45^{\circ}$ & $\left(45^{\circ}\right)$ & & $\rightarrow$ & 11.89 & 10.89 \\
\hline $52.5^{\circ}$ & $\left(52.5^{\circ}\right)$ & & & 6.39 & 7.02 \\
\hline $60^{\circ}$ & $\left(60^{\circ}\right)$ & & $\longrightarrow$ & 3.41 & 4.17 \\
\hline $75^{\circ}$ & $\left(75^{\circ}\right)$ & & & 2.12 & 4.18 \\
\hline $90^{\circ}$ & $61^{\circ}$ & 9.10 & 14.61 & 3.83 & 5.11 \\
\hline \multicolumn{6}{|l|}{$\langle\langle C D-3\rangle$} \\
\hline Intact & $63^{\circ}$ & 11.77 & 17.21 & 7.34 & 8.51 \\
\hline $0^{\circ}$ & $60^{\circ}$ & 13.47 & 18.13 & 9.96 & 12.06 \\
\hline $15^{\circ}$ & $61^{\circ}$ & 11.87 & 15.99 & 9.20 & 11.19 \\
\hline $30^{\circ}$ & $63^{\circ}$ & 10.23 & 14.18 & 7.15 & 8.15 \\
\hline $37.5^{\circ}$ & $58^{\circ}$ & 13.59 & 19.48 & 10.67 & 12.28 \\
\hline $45^{\circ}$ & $\left(45^{\circ}\right)$ & & & 18.01 & 15.01 \\
\hline $52.5^{\circ}$ & $\left(52.5^{\circ}\right)$ & & & 12.21 & 12.01 \\
\hline $60^{\circ}$ & $\left(60^{\circ}\right)$ & & & 8.32 & 9.21 \\
\hline $75^{\circ}$ & $\left(75^{\circ}\right)$ & & & 4.68 & 6.28 \\
\hline $90^{\circ}$ & $63^{\circ}$ & 10.17 & 14.07 & 7.55 & 8.93 \\
\hline \multicolumn{6}{|l|}{$\langle C D-6\rangle$} \\
\hline Intact & $60^{\circ}$ & 17.75 & 20.34 & 13.90 & 13.67 \\
\hline $0^{\circ}$ & $63^{\circ}$ & 14.95 & 17.57 & 12.20 & 12.18 \\
\hline $15^{\circ}$ & $62^{\circ}$ & 15.68 & 18.21 & 13.22 & 13.59 \\
\hline $30^{\circ}$ & $62^{\circ}$ & 15.59 & 18.04 & 14.27 & 15.55 \\
\hline $45^{\circ}$ & $60^{\circ}$ & 16.41 & 18.02 & 14.21 & 14.21 \\
\hline $52.5^{\circ}$ & $\left(52.5^{\circ}\right)$ & & & 19.54 & 17.65 \\
\hline $60^{\circ}$ & $\left(60^{\circ}\right)$ & & 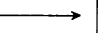 & 13.27 & 12.59 \\
\hline $75^{\circ}$ & $\left(75^{\circ}\right)$ & & 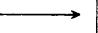 & 8.27 & 8.49 \\
\hline $90^{\circ}$ & $62^{\circ}$ & 14.67 & 16.30 & 12.72 & 12.64 \\
\hline \multicolumn{6}{|l|}{$\langle\mathrm{CD}-10\rangle$} \\
\hline Intact & $64^{\circ}$ & 19.26 & 18.57 & 16.30 & 12.63 \\
\hline $45^{\circ}$ & $63^{\circ}$ & 19.37 & 18.40 & 18.18 & 16.06 \\
\hline $52.5^{\circ}$ & $65^{\circ}$ & 18.01 & 17.17 & 16.83 & 14.65 \\
\hline $60^{\circ}$ & $\left(60^{\circ}\right)$ & & 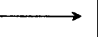 & 19.42 & 16.31 \\
\hline $67.5^{\circ}$ & $\left(67.5^{\circ}\right)$ & & - & 15.61 & 13.53 \\
\hline $75^{\circ}$ & $60^{\circ}$ & 21.19 & 19.38 & 17.92 & 13.71 \\
\hline$\langle C D-20\rangle$ & & & & & \\
\hline $60^{\circ}$ & $\left(60^{\circ}\right)$ & & $\longrightarrow$ & 31.35 & 19.66 \\
\hline
\end{tabular}

図より明らかなように破壊形態は，既存の切断面に沿 ってすべり破壊を生ずる場合と，切断面に無関係に新た な破断面を生ずる場合の 2 つに分けられる．さらにす心゙ り破壊を生じる切断面の角度の範囲は, 拘束圧が高くな るにつれて狭くなってくるのがわかる.すなわち CD1, CD-3 では, $45^{\circ}, 52.5^{\circ}, 60^{\circ}, 75^{\circ}$ の角度を有する供試 体は切断面に沿ったすべり破壊がみられるのに対して， CD-6 では, $52.5^{\circ}, 60^{\circ}, 75^{\circ}, \mathrm{CD}-10$ に至ると $60^{\circ}$ 之 $67.5^{\circ}$ の角度を有する供試体についてのみすべり破壊が 生じている.しかし CD-10 において，新たな破断面を 生じる場合には，破断面に沿ったせん断変形のみならず 全般的な樽型変形も生じているのが観察される.この現 象は, CD-10 の最大強度時の応力状態が遷移応力（先

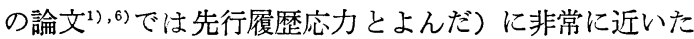




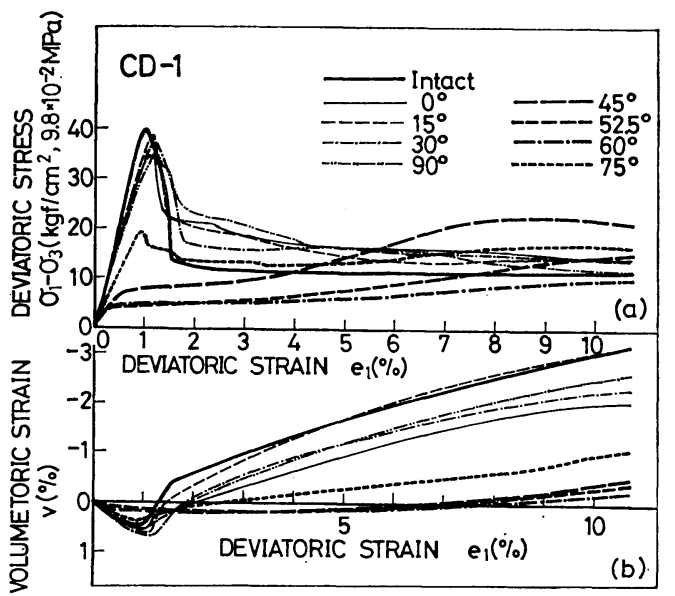

図-4 応力〜ひずみ関係（CD-1）

(a) 軸差応力-偏差ひずみ

(b) 体積ひずみ-偏差ひずみ関係

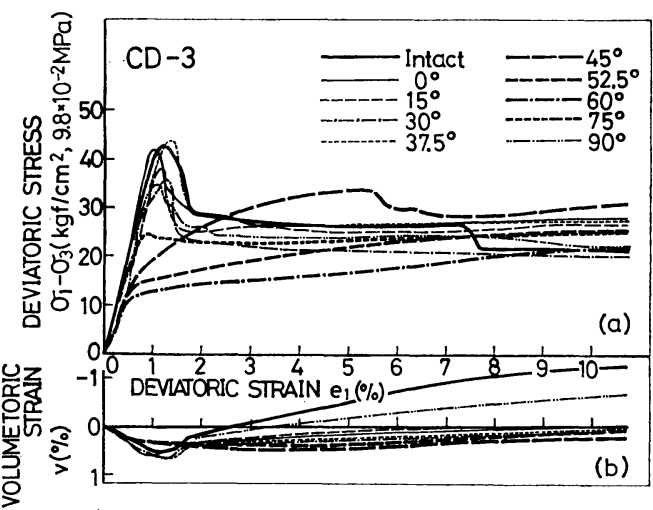

図一5 応力〜ひずみ関係（CD-3）

(a) 軸差応力-偏差ひずみ

(b) 体積ひずみ-偏差ひずみ関係
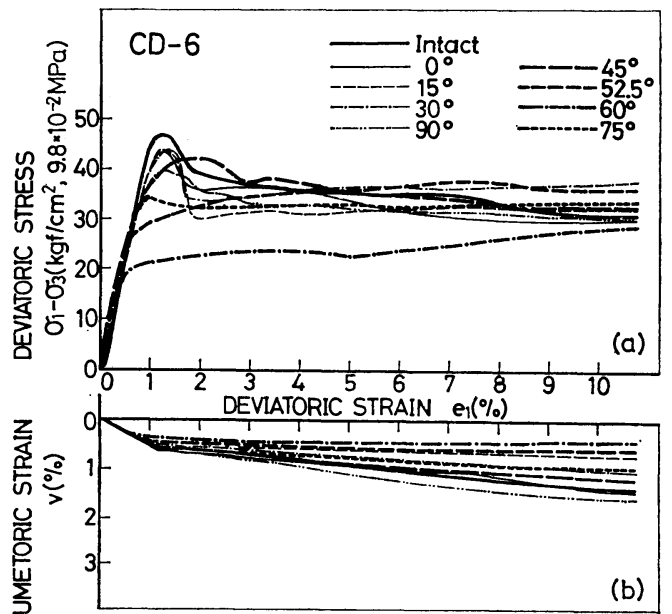

図一6 応力〜ひずみ関係 (CD-6)

(a) 軸差応力-偏差ひずみ

（b）体積ひずみ-偏差ひずみ関倸
めと考えられる.なお，CD-20 については $60^{\circ}$ の供試 体 1 本しか実験を行っていないが，破壊形態は切断面に 沿ったすべりも，新しく破断面が入ることもなく，ただ 樽型変形を生じただけであった.これより CD-20 にょ いては, 破壊時の忍力が遷移応力を超えており, 切断面 の有無およびその角度がもはや強度に影響を与えないも
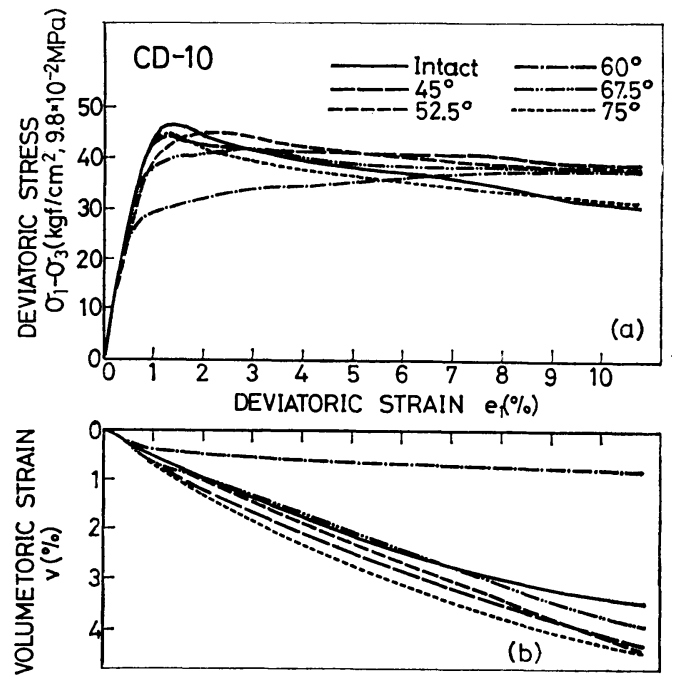

図一7 応カ〜ひずみ関係 $($ CD-10)

(a) 軸差応力-偏差ひずみ

（b）体積ひずみ-偏差ひずみ閣倸
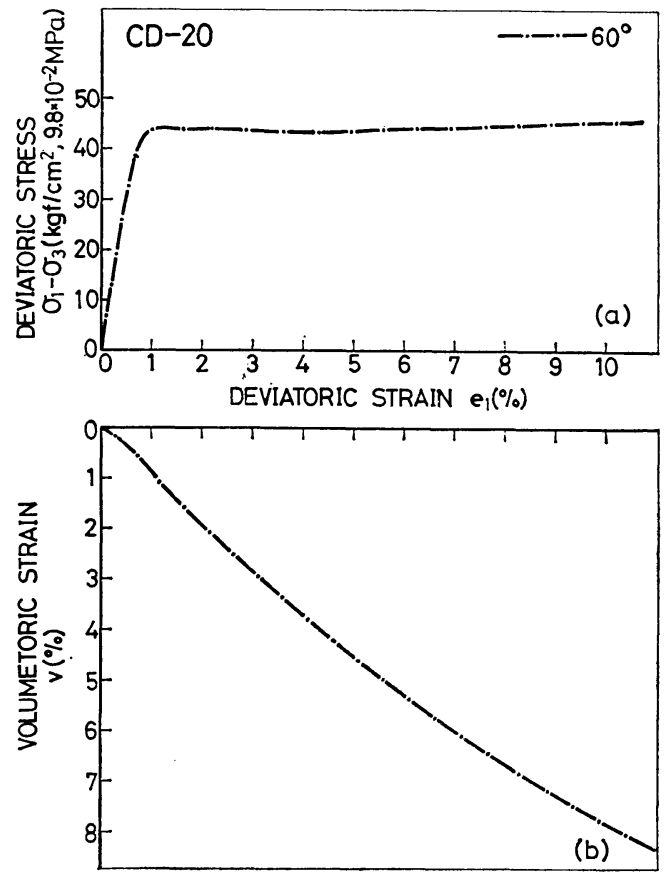

図一8 応力〜ひずみ関係 (CD-20)

(a) 軸差応力-偏差ひずみ

（b）体積ひずみ-偏差ひずみ関係 
のと考えられる.

\section{（2）応力〜ひずみ関係}

図一4〜8 は各側圧に対する応力〜ひずみ関係を，(a) に軸差応力〜偏差ひずみ関係，(b) に体積ひずみ〜偏差 ひずみ関係で示した.また, それぞれの最大強度, 残留 強度の值は表一3 にまとめて与えている.

破壊形態の相違によって，2 種の応力〜ひずみ関係に 分けることができる.切断面に関係なく新しく破断面が 生じた供試体は, Intact rock とほぼ等しい曲線となり, 軸差応力〜偏差ひずみ関係は “ひずみ硬化〜軟化型”, 体積変化も低拘束圧下では顥著な正のダイレタンシー, 拘束圧が高くなるにつれて負のダイレタンシー挙動を示 す. 他方, 切断面に沿ったすべり破壊を生じた供試体に
ついては，軸差応力〜偏差ひずみ関係は “ひずみ硬化 型”となり，かつ顕著なダイレタンシー挙動を示さな い.これはせん断のごく初期より, 変形が切断面の近辺 に制限されることによって残留応力状態, すなわち有効 応力も体積も変化しない状態に達するためと考えられ る.

なお， CD-1，3，6 の $75^{\circ}$ に対する応力〜ひずみ関係 は，切断面に沿うすべり破壊にもかかわらずピークをも つが，この理由は $75^{\circ}$ の切断面が供試体の端面を切るた め, せん断初期に端部のくさび部分による抵抗を受ける ためで, 試験上の問題に起因していると考えられる.

切断面の有無と角度による応力〜ひずみ関係の差異 は，拘束圧が高くなるに従って次第に消滅することは明 らかである。
表-3 弾 性 係 数

\begin{tabular}{|c|c|c|c|c|c|c|}
\hline & \multicolumn{2}{|c|}{ SHEAR MODULUS $G$} & \multicolumn{2}{|c|}{ BULK MODULUS $K$} & \multirow[b]{2}{*}{ 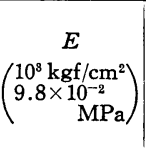 } & \multirow[b]{2}{*}{$\nu$} \\
\hline & $\left(\begin{array}{c}G \\
10^{3} \mathrm{kgf} / \mathrm{cm}^{2} \\
9.8 \times 10^{-2} \\
\mathrm{MPa}\end{array}\right)$ & $G / G_{I}$ & $\left(\begin{array}{c}K \\
\left(\begin{array}{c}10^{3} \mathrm{kgf} / \mathrm{cm}^{2} \\
9.8 \times 10^{-2} \\
\mathrm{MPa}\end{array}\right)\end{array}\right.$ & $K / K_{I}$ & & \\
\hline \multicolumn{7}{|l|}{$\langle C \mathrm{CD}-1\rangle$} \\
\hline Intact & 1.57 & 1.00 & 2.73 & 1.00 & 3.95 & 0.26 \\
\hline $0^{\circ}$ & 1.12 & 0.71 & 1.85 & 0.68 & 2.79 & 0.25 \\
\hline $15^{\circ}$ & 1.27 & 0.81 & 2.16 & 0.79 & 3.19 & 0.25 \\
\hline $30^{\circ}$ & 1.17 & 0.74 & 1.71 & 0.62 & 2.86 & 0.22 \\
\hline $45^{\circ}$ & 0.58 & 0.37 & 1.45 & 0.53 & 1.53 & 0.32 \\
\hline $52.5^{\circ}$ & 0.54 & 0.35 & 1.19 & 0.43 & 1.41 & 0.30 \\
\hline $60^{\circ}$ & 0.52 & 0.33 & 0.80 & 0.29 & 1.27 & 0.24 \\
\hline $75^{\circ}$ & 0.73 & 0.47 & 1.45 & 0.53 & 1.87 & 0.28 \\
\hline $90^{\circ}$ & 1.07 & 0.68 & 1.70 & 0.62 & 2.65 & 0.24 \\
\hline \multicolumn{7}{|l|}{$\langle C D-3\rangle$} \\
\hline Intact & 1.50 & 1.00 & 2.61 & 1.00 & 3.79 & 0.26 \\
\hline $0^{\circ}$ & 1.97 & 1.31 & 2.14 & 0.82 & 4.52 & 0.15 \\
\hline $15^{\circ}$ & 1.12 & 0.74 & 2.09 & 0.80 & 2.85 & 0.27 \\
\hline $30^{\circ}$ & 1.86 & 1.24 & 2.01 & 0.77 & 4.26 & 0.15 \\
\hline $37.5^{\circ}$ & 1.09 & 0.72 & 2.13 & 0.82 & 2.79 & 0.28 \\
\hline $45^{\circ}$ & 0.89 & 0.59 & 1.56 & 0.60 & 2.24 & 0.26 \\
\hline $52.5^{\circ}$ & 1.02 & 0.68 & 1.46 & 0.56 & 2.48 & 0.22 \\
\hline $60^{\circ}$ & 0.92 & 0.61 & 1.17 & 0.45 & 2.18 & 0.19 \\
\hline $75^{\circ}$ & 1.12 & 0.75 & 1.92 & 0.74 & 2.82 & 0.26 \\
\hline $90^{\circ}$ & 1.26 & 0.84 & 2.04 & 0.78 & 2.95 & 0.23 \\
\hline \multicolumn{7}{|l|}{$\langle C D-6\rangle$} \\
\hline Intact & 1.83 & 1.00 & 3.14 & 1.00 & 4.59 & 0.26 \\
\hline $0^{\circ}$ & 1.45 & 0.80 & 2.38 & 0.76 & 3.62 & 0.25 \\
\hline $15^{\circ}$ & 1.50 & 0.82 & 3.11 & 0.99 & 3.88 & 0.29 \\
\hline $30^{\circ}$ & 1.42 & 0.78 & 3.11 & 0.99 & 3.69 & 0.30 \\
\hline $45^{\circ}$ & 1.68 & 0.92 & 2.62 & 0.84 & 4.16 & 0.24 \\
\hline $52.5^{\circ}$ & 1.69 & 0.92 & 2.34 & 0.75 & 4.08 & 0.21 \\
\hline $60^{\circ}$ & 1.29 & 0.71 & 2.08 & 0.66 & 3.21 & 0.24 \\
\hline $75^{\circ}$ & 1.52 & 0.83 & 2.58 & 0.82 & 3.79 & 0.25 \\
\hline $90^{\circ}$ & 1.48 & 0.81 & 3.11 & 0.99 & 3.83 & 0.30 \\
\hline \multicolumn{7}{|l|}{$\langle C D-10\rangle$} \\
\hline Intact & 1.76 & 1.00 & 2.97 & 1.00 & 4.41 & 0.25 \\
\hline $45^{\circ}$ & 1.83 & 1.04 & 2.74 & 0.92 & 4.49 & 0.23 \\
\hline $52.5^{\circ}$ & 1.56 & 0.88 & 2.32 & 0.78 & 3.82 & 0.23 \\
\hline $60^{\circ}$ & 1.76 & 1.00 & 3.55 & 1.19 & 4.53 & 0.29 \\
\hline $67.5^{\circ}$ & 1.61 & 0.91 & 2.28 & 0.77 & 3.91 & 0.21 \\
\hline $75^{\circ}$ & 1.79 & 1.02 & 2.72 & 0.92 & 4.40 & 0.23 \\
\hline \multicolumn{7}{|l|}{$\langle C D-20\rangle$} \\
\hline $60^{\circ}$ & 2.30 & 1.00 & 3.74 & 1.00 & 5.73 & 0.24 \\
\hline
\end{tabular}

\section{（3）切断面の弾性係数に与える影響}

切断面の有無および角度が，せん断弾性 係数 $G$, 体積弾性係数 $K$ にどのような影 響を及ぼすかを調べてみた。図一9，10 は その結果を示している. なお $G, K$ は，応 カ〜ひずみ関係の初期直線部分より，それ ぞれ次式を用いて計算した。

$$
\begin{aligned}
& G=\left(\sigma_{1}-\sigma_{3}\right) / 3 e_{1} \\
& K=\left(\sigma_{1}-\sigma_{3}\right) / 3 v
\end{aligned}
$$

表一3 にはこの結果求まる $G, K$ の值，お よび Intact rock の弾性係数 $G_{I}, K_{I}$ で それぞれ規準化した $G / G_{I}, K / K_{I}$ の值を 与えている.

例外は認められるが, 切断面を有する供 試体より求まる $G, K$ の值は, Intact rock の值よりも小さく, 特に切断面に沿ってす ベり破壊を生じた供試体については，その 值の低下の度合は大きいといえる.また， その傾向は低拘束圧で顕著であり，拘束圧 が高くなるにつれて切断面の弾性係数に与 える影響は次第に減少する。

切断面に関係なく新たに破断面を生じた 供試体に対する $G, K$ も Intact rock の值 より小さいが，これは切断面の存在に起因 するものと考えられる. すなわち, 元来供 試体をセットした状態において, 切断面間 の接触は点接触であるが，その後圧密を， さらにせん断を行うことによって，点接触 は弾性変形, 圧潰および引張り亀裂の発生 によって接触面積を広める.したがって， せん断初期に供試体全体の弾性変形に加え て, 上述した切断面間の局部的な変形も同 
$C D-1$ $\mathrm{CD}-3$ CD-6

CD -10

$\mathrm{G}_{1}=1.57 \times 10^{3} \mathrm{kgt} / \mathrm{cm}^{2} \quad \mathrm{G}_{\mathrm{I}}=1.50 \times 10^{3} \mathrm{kgf} / \mathrm{cm}^{2}$

$G_{1}=1.83 \times 1 C$

$\mathrm{G}_{1}=1.76 \times 10^{3} \mathrm{kgf} / \mathrm{cm}^{2}$ $90^{\circ} 75^{\circ} \quad\left(1.54 \times 10^{2} \mathrm{MPa}\right) 90^{\circ} 75^{\circ} \quad\left(1.47 \times 10^{2} \mathrm{MPa}\right) 90^{\circ} 75^{\circ} \quad\left(1.79 \times 10^{2} \mathrm{MPa}\right) 90^{\circ} 0^{75^{\circ}}\left(1.72 \cdot 10^{2} \mathrm{MPa}\right)$
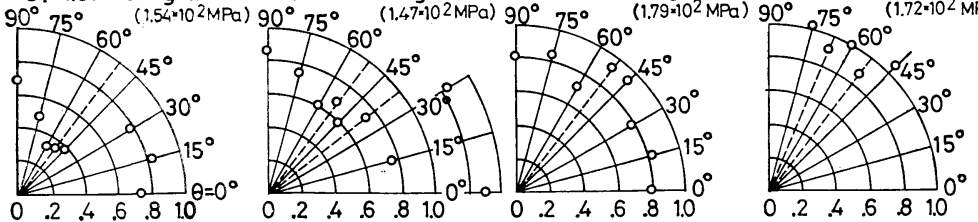

SHEAR MODULUS $G / G_{I}$

\section{図一9 せん断弾性係数 $G$ に及ぼす切断面の影響}

CD -1 $\mathrm{CD}-3$

CD -6

$\mathrm{CD}-10$

$\mathrm{K}_{1}=2.73 \times 10^{3} \mathrm{kgf} / \mathrm{cm}^{2} \quad \mathrm{~K}_{1}=2.61 \times 10^{3} \mathrm{kgf} / \mathrm{cm}^{2} \quad \mathrm{~K}_{1}=3.14 \times 10^{3} \mathrm{kgf} / \mathrm{cm}^{2} \quad \mathrm{Kl}_{1}=2.97 \times 10^{3} \mathrm{kgf} / \mathrm{cm}^{2}$

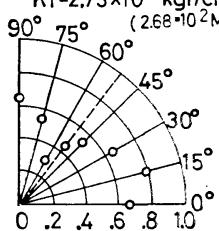
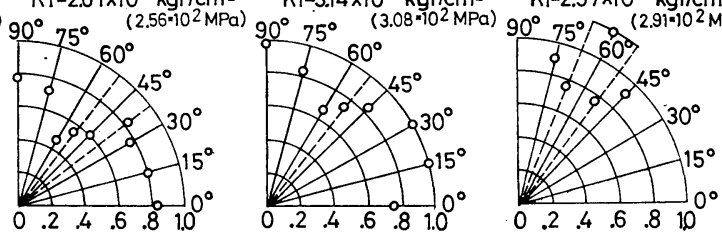

Hobbs, ${ }^{2)}$ Murrell $^{3)}$ らが岩石質 材料に対して提唱しているべき 関数型の条件式による方が，適 合性のよいことが明らかにされ ている.

本研究に用いた泥岩に対し て, ベき関数型の破壊規準式の 適用性の可否をまず検討してみ る.ただし先の研究 ${ }^{1), 6)}$ のよう に, 平均有効応力; $\sigma_{m}{ }^{\prime}=\left(\sigma_{1}{ }^{\prime}+\right.$ $\left.2 \sigma_{3}{ }^{\prime}\right) / 3 \sim$ 軸差応力; $\sigma_{1}-\sigma_{3}$ 関 係, もしくは平均応力; $\sigma_{n}{ }^{\prime}=$ $\left(\sigma_{1}{ }^{\prime}+\sigma_{3}{ }^{\prime}\right) / 2 \sim$ せん断応力; $\left(\sigma_{1}\right.$ $\left.-\sigma_{3}\right) / 2$ 関係で議論するのでは なく, 破壊をより直接的に解析 するために, 既存の切断面に沿 ってすべり破壊を生じたものに ついては切断面上に作用する，

また切断面に関係なく破壊した

\section{図一10 体積弾性係数 $K$ に及ぼす切断面の影響}

時に生ずるから，結局全体的な弾性係数の值を低下させ るものと考えられる. 特に低拘束圧では圧密終了時, 寸 なわちせん断直前の切断面間の間隔が広いと思われるか ら, 弾性係数の低下の度合も大きくなると考えられる.

さて, 切断面に沿うすべり破壊を生じる供試体の弾性 係数が, ほかに比較してさらに小さな值をとるのは, 初 期のせん断過程において上述の変形挙動（弾性変形なら びに切断面間の接触面積の拡大）に加え, 切断面に沿っ たすべり変形もある程度発生するためによると考えられ る. したがって最大主応力作用面に対して切断面の角度 が $60^{\circ}$ であると最もすべりやすく, 弾性係数がその最小 值をとるものと考えられる.

ヤング率 $E$, ポアソン比 $\nu$ は $G, K$ より次式で計算 される. その結果を 表一3 に与えている.

$$
E=\frac{9 K G}{3 K+G}, \nu=\frac{3 K-2 G}{2(3 K+G)}
$$

表において, ヤング率 $E$ は， $G, K$ と同様低拘束圧 においては, 切断面の有無および角度の影響を受ける が，拘束圧が大きくなるに従ってその影響は次第に減少 することがわかる. 一方, ポアソン比 $\nu$ は, 切断面の 有無拉よび角度の影響, ならびに拘束圧による影響も認 内られず, 本泥岩試料に対して平均值は, る.

\section{（4）不連続面を有する軟岩の破壊規準}

大谷石 (多孔質の堆積軟岩) に関する従来の研究 ${ }^{1,6)}$ によって, 最大強度, 残留強度に対する破壊規準は, $c$, るを用いた Mohr-Coulombの条件式によるよりも，
ものについては，その破断面上に作用する有効垂直応力 $\sigma^{\prime}$ とせん断応力 $\tau$ の関係によって, その議論を行うこ とにする.

図一11 は，表—2 に示す $\sigma_{P}{ }^{\prime}, \tau_{P}$ ならびに $\sigma_{R}{ }^{\prime}, \tau_{R}$, すなわち最大強度時ならびに残留強度時の垂直応力 $\sigma^{\prime}$, せん断応力 $\tau$ の值をプロットしたものである. 図におい て破壊時の $\sigma^{\prime} \sim \tau$ 関係は，2 本の曲線によって表わされ ることがわかる.すなわち新しくせん断破壊するものに ついては, 従来どおり最大強度曲線, 残留強度曲線で表 わされるが, 切断面に沿うすべり破壊を生じるものにつ いては, 最大=残留強度となり, 前者の残留強度曲線に 一致する. 図一12 は, これらの関係を両対数紙上に求 め直したものである. 図一11 における 2 本の曲線は, それぞれ勾配の異なる 2 本の直線で表わされることがわ

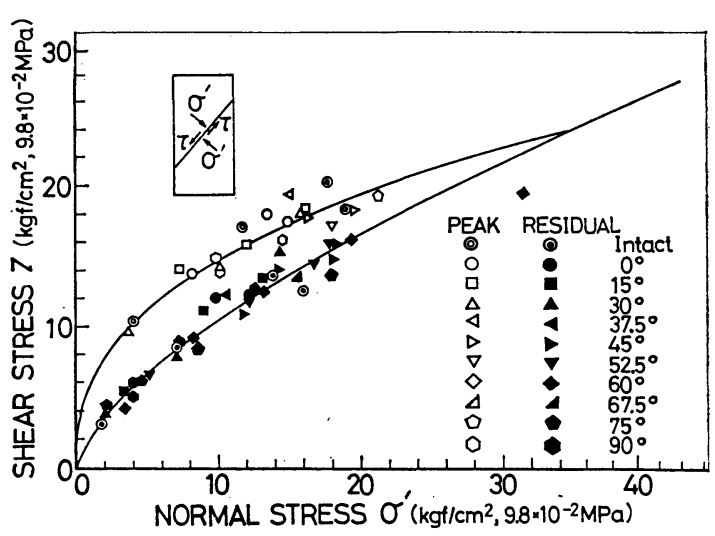

図一11 破断面もしくは切断面上に作用する応力関係 による最大強度および残留強度 $\left(\sigma^{\prime} \sim \tau\right.$ 関係 $)$ 


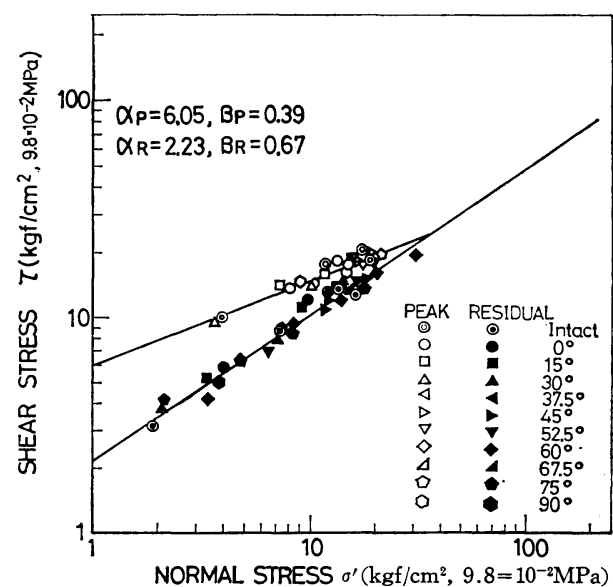

図一12 最大強度, 残留強度の両対数表示 $\left(\sigma^{\prime} \sim \tau\right.$ 関係)

かる. したがって， $\sigma^{\prime} \sim \tau$ 関係で求めた 2 本の曲線は， 双方ともべき関数型の破壊条件式で表わすことができ， 不連続面を有する軟岩の破壊規準を次式のように定義で きる.

（1）不連続面（切断面）に関係なく新たに破断面が 生じる場合

(i ) 最大強度

遷移応力以下 $\left(\tau / \sigma_{0}{ }^{\prime}\right)_{\text {peak }}=\alpha_{P}\left(\sigma^{\prime} / \sigma_{0}{ }^{\prime}\right)^{\beta_{P} \ldots(4)}$

遷移応力以上 $\left(\tau / \sigma_{0}{ }^{\prime}\right)_{\text {peak }}=\left(\tau / \sigma_{0}\right)_{\text {residual }}$ $(4)^{\prime}=(5)$

(ii) 残留強度

$\left(\tau / \sigma_{0}{ }^{\prime}\right)_{\text {residual }}=\alpha_{R}\left(\sigma^{\prime} / \sigma_{0}{ }^{\prime}\right)^{\beta_{R}}$

（2）不連続面（切断面）に沿うすべり破壊を生じる 場合

最大 $=$ 残留強度 $\left(\tau / \sigma_{0}{ }^{\prime}\right)_{\text {peak, }}$, residual $=\alpha_{R}\left(\sigma^{\prime} / \sigma_{0}{ }^{\prime}\right)^{\beta_{R}} \ldots \ldots \ldots(5)$

ただし， $\sigma_{0}{ }^{\prime}$ は単位応力 $=1 \mathrm{kgf} / \mathrm{cm}^{2}\left(9.8 \times 10^{-2} \mathrm{MPa}\right)$ で ある。

式 (4)，(4)' および（5）で与えられる破壊規準は， 切断面および破断面に作用する応力の関係を直接表わし ているから, Intact rock のみならず不連続面（切断面） を有する岩石に対する統一的な破壊規準となる．したが って, 式中の強度定数 $\alpha_{P}, \beta_{P}, \alpha_{R}, \beta_{R}$ は, 対象とする 岩石に対してはその岩石固有の材料定数となる.

なお，本研究で用いた泥岩の強度定数值は 図一12に 与えてあるが, 図一11 中実線で表わす曲線は, この $\alpha_{P}$, $\beta_{P}, \alpha_{R}, \beta_{R}$ の值を式 (4), (5) 亿代入して求めた曲線で ある. 図において，遷移応力は，打およそ $\sigma^{\prime}=35 \mathrm{kgf} /$ $\mathrm{cm}^{2}(3.4 \mathrm{MPa})$ であり，有効拘束圧 $\sigma_{3}{ }^{\prime}$ に換算すると， $\sigma_{3}{ }^{\prime}=16.7 \mathrm{kgf} / \mathrm{cm}^{2}(1.6 \mathrm{MPa})$ となる.

\section{（5）不連続面を有する軟岩の破壊機構}

先に述べた不連続面（切断面）を有する軟岩の 2 種類

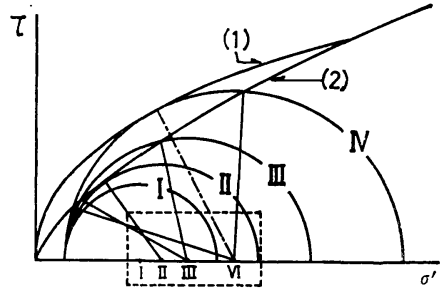

（a）Mohr の応力円で表わした岩石のせん断過程

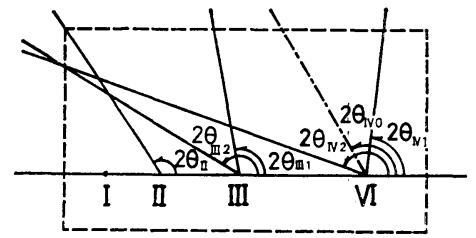

(b) 搪大四

図-13

の破壊形態について，その相違を破壊機構に基ゔいて検 討を加える.これまでにも不連続面を有する岩石の力学

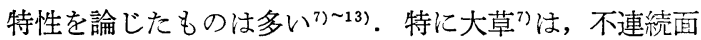
の角度と拘束圧が岩石の力学挙動に与える影響を詳しく 論じている. しかしその議論は, 岩石のせん断強さが Mohr-Coulombの破壊規準に従うといら仮定に基づいて いる. そこで本研究においては, 式 (4) と式 (5) の破 壊規準を用いて大草の議論を拡張する方向で破壊機構を 考察することとする.

図一13(a) は，ある所定の拘束圧のもとでのせん断過 程をMohr の応力円を用いて表わしたものである. 図中 の 2 本の曲線は，式 (4)，(5) で表わされる破壊規準で あり，（1）が最大強度曲線，（2）が残留強度曲線 であ る.また，(b) には（a）の点線で囲まれた部分の拡大 図を示した．以下，各応力円におけるせん断変形の状態 について考えてみる.

(1) 応力円 I

この状態では, 切断面の有無およびその角度にかかわ らず，すべての岩石供試体にはすべりが生じない。

(2) 応力円II

これは, 応力円が残留強度曲線と接している状態であ る.この場合, 供試体が最大主応力作用面と $\theta=\theta_{\text {II }}$ の角 度をなす切断面を有していると，切断面に沿ってす心゙り が生じる. しかし， $\theta=\theta_{\text {II }}$ 以外の切断面を有するもので は，すべり破壞は生じない。

\section{(3) 応力円III}

応力円が残留強度曲線と 2 点で交わるが, 最大強度曲 線とは接しない応力状態である.この場合, 供試体が $\theta$ $=\theta_{\text {II1 }}, \theta_{\text {II2 } 2}$ の切断面を有しておれば，切断面に沿ったす ベり破壊が生じる.

(4) 応力円IV 
これは, 応力円が最大強度曲線と接している状態であ る.この応力状態に至ると，すべての供試体は破壊す る. 新しく破壊面が生じる場合は，そのせん断角は $\theta_{\mathrm{IV} 0}$ となり，切断面の角度が $\theta=\theta_{\mathrm{N} 1}$ もしくは $\theta_{\mathrm{N} 2}$ であると， 切断面に沿ったすべり破壊を生ずる.したがって，角度 $\theta$ が $\theta_{\mathrm{IV} 1}<\theta<\theta_{\mathrm{N} 2}$ の範囲にある供試体は, 応力円がII からIVに至るまでに，切断面に沿うすべり破壊がすでに 生じていることになる.

上述のような破壊機構によって切断面を有する軟岩の 破壊を説明できるものとすると，次の結論が得られる．

（1）切断面を有する供試体をある拘束圧のもとでせ ん断させた場合，切断面に沿ったすべり破壊を生じる角 度の範囲は図一14のように決定され，その範囲は $\theta_{1} \leqq$ $\theta \leqq \theta_{2}$ である.

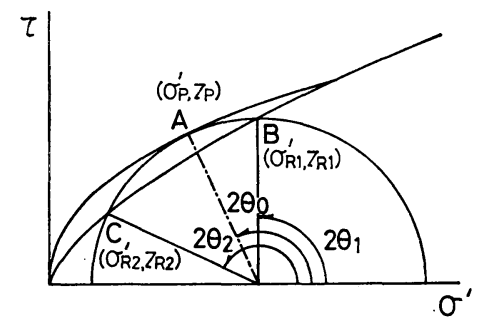

図一14 角度 $\theta_{0}, \theta_{1}, \theta_{2}$ を決定する 3 点 $\mathrm{A}, \mathrm{B}, \mathrm{C}$

（2）切断面に関倸なく新たに破断面が生じる場合 は， $\theta=\theta_{0}$ の角度で破断する.

なお, $\theta_{0}, \theta_{1}, \theta_{2}$ の值は, 図一14 中の 3 点 $\mathrm{A}\left(\sigma_{P}{ }^{\prime}, \tau_{P}\right)$, $\mathrm{B}\left(\sigma_{R_{1}}{ }^{\prime}, \tau_{R_{1}}\right), \mathrm{C}\left(\sigma_{R_{2}}{ }^{\prime}, \tau_{R_{2}}\right)$ の值を用いることで, 次式 により決定できる。

$$
\begin{aligned}
& \theta_{0}=\frac{1}{2} \sin ^{-1}\left(\frac{\tau_{P}}{\sigma_{3}{ }^{\prime}-\sigma_{n}{ }^{\prime}}\right)=\frac{1}{2} \sin ^{-1}\left(\frac{\alpha_{P} \sigma^{\prime}{ }_{P}{ }^{\beta_{P}}}{\sigma_{3}{ }^{\prime}-\sigma_{n}{ }^{1}}\right) \\
& \theta_{1}=\frac{1}{2} \sin ^{-1}\left(\frac{\tau_{R_{1}}}{\sigma_{3}{ }^{\prime}-\sigma_{n}{ }^{\prime}}\right)=\frac{1}{2} \sin ^{-1}\left(\frac{\alpha_{R} \sigma_{R_{1}}{ }^{\prime} \beta_{R}}{{\sigma_{3}{ }^{\prime}-\sigma_{n}{ }^{\prime}}^{\prime}}\right) \\
& \theta_{2}=\frac{1}{2} \sin ^{-1}\left(\frac{\tau_{R_{2}}}{\sigma_{3}{ }^{\prime}-\sigma_{n}{ }^{\prime}}\right)=\frac{1}{2} \sin ^{-1}\left(\frac{\alpha_{R} \sigma_{R_{2}}{ }^{\prime \beta_{R}}}{{\sigma_{3}{ }^{\prime}-\sigma_{n}{ }^{\prime}}}\right)
\end{aligned}
$$

ここで, $\frac{\sigma_{n}{ }^{\prime}}{\sigma_{0}{ }^{\prime}}=\frac{\sigma_{1}{ }^{\prime}+\sigma_{3}{ }^{\prime}}{2 \sigma_{0}{ }^{\prime}}=\alpha_{P}{ }^{2} \beta_{P}\left(\frac{\sigma_{P}{ }^{\prime}}{\sigma_{0}{ }^{\prime}}\right)^{2 \beta_{P}-1}+\left(\frac{\sigma_{P}{ }^{\prime}}{\sigma_{0}{ }^{\prime}}\right)$ で ある.なお, 式中の $\sigma_{P}{ }^{\prime}, \sigma_{R_{1}}{ }^{\prime}, \sigma_{R_{2}}{ }^{\prime}$ は次式を解析して求 められる。

$\sigma_{P}^{\prime}$ に関して,

$$
\begin{gathered}
\alpha_{P}{ }^{2}\left(2 \beta_{P}-1\right)\left(\frac{\sigma_{P}{ }^{\prime}}{\sigma_{0}{ }^{\prime}}\right)^{2 \beta_{P}}-2 \alpha_{P}{ }^{2} \beta_{P}\left(\frac{\sigma_{3}{ }^{\prime}}{\sigma_{0}{ }^{\prime}}\right)\left(\frac{\sigma_{P}{ }^{\prime}}{\sigma_{0}{ }^{\prime}}\right)^{2 \beta_{P}-1} \\
+\left(\frac{\sigma_{P}{ }^{\prime}}{\sigma_{0}{ }^{\prime}}\right)^{2}-2\left(\frac{\sigma_{3}{ }^{\prime}}{\sigma_{0}{ }^{\prime}}\right)\left(\frac{\sigma_{P}{ }^{\prime}}{\sigma_{0}{ }^{\prime}}\right)+\left(\frac{\sigma_{3}{ }^{\prime}}{\sigma_{0}{ }^{\prime}}\right)^{2}=0 \cdots(9)
\end{gathered}
$$

$\sigma_{R_{1}}{ }^{\prime}, \sigma_{R_{2}}{ }^{\prime}$ に関して，

$\alpha_{R}{ }^{2}\left(\frac{\sigma_{R}{ }^{\prime}}{\sigma_{0}{ }^{\prime}}\right)^{2 \beta_{R}}+\left(\frac{\sigma_{R}{ }^{\prime}}{\sigma_{0}{ }^{\prime}}\right)^{2}-2\left(\frac{\sigma_{n}{ }^{\prime}}{\sigma_{0}{ }^{\prime}}\right)\left(\frac{\sigma_{R}{ }^{\prime}}{\sigma_{0}{ }^{\prime}}\right)$

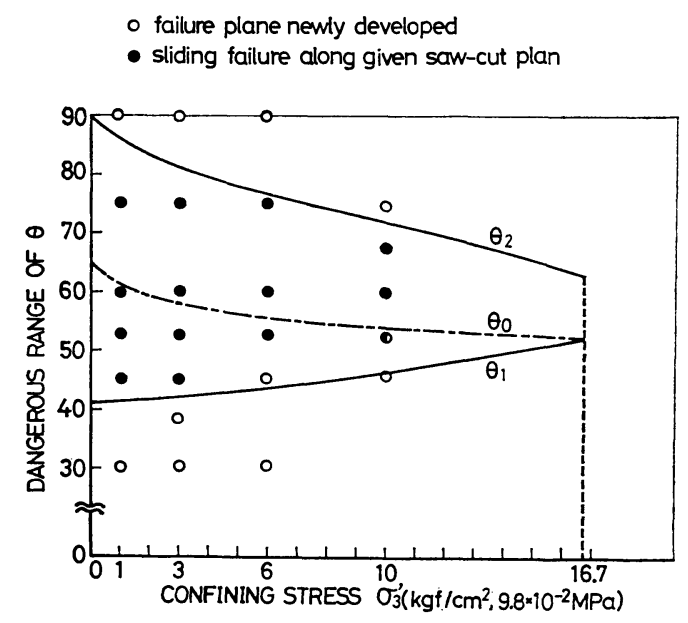

\begin{tabular}{|c|c|c|c|}
\hline $\begin{array}{c}\sigma_{3^{\prime}} \\
\left(\begin{array}{l}\mathrm{kgf} / \mathrm{cm}^{2} \\
9.8 \times 10^{-2} \mathrm{MPa}\end{array}\right)\end{array}$ & $\theta_{0}^{\circ}$ & $\theta_{1}^{\circ}$ & $\theta_{2}^{\circ}$ \\
\hline 0 & 64.9 & 40.9 & 90.0 \\
\hline 1 & 61.0 & 41.2 & 85.7 \\
\hline 2 & 59.1 & 41.6 & 83.3 \\
\hline 3 & 57.9 & 42.1 & 81.4 \\
\hline 4 & 57.0 & 42.6 & 79.7 \\
\hline 5 & 56.3 & 43.2 & 78.2 \\
\hline 6 & 55.7 & 43.8 & 76.9 \\
\hline 7 & 55.2 & 44.4 & 75.6 \\
\hline 8 & 54.8 & 45.0 & 74.3 \\
\hline 9 & 54.4 & 45.6 & 73.1 \\
\hline 10 & 54.1 & 46.3 & 71.9 \\
\hline 11 & 53.8 & 47.0 & 70.8 \\
\hline 12 & 53.5 & 47.8 & 69.6 \\
\hline 13 & 53.2 & 48.6 & 68.4 \\
\hline 14 & 53.0 & 49.5 & 67.1 \\
\hline 15 & 52.8 & 50.4 & 65.8 \\
\hline 16 & 52.6 & 51.6 & 64.3 \\
\hline 16.7 & 52.5 & 52.5 & 63.2 \\
\hline
\end{tabular}

図一15 すべり破壊を生ずる切断面の角度と拘束圧の関係

\section{表一4 計算により求められる，新たに破断面を 生じたときの破断面の角度 $\theta_{0}$ ならびに すべり破壊を生ずる角度の範囲 $\theta_{1}, \theta_{2}$}

$+2\left(\frac{\sigma_{n}{ }^{\prime}}{\sigma_{0}{ }^{\prime}}\right)\left(\frac{\sigma_{3}{ }^{\prime}}{\sigma_{0}{ }^{\prime}}\right)-\left(\frac{\sigma_{3}{ }^{\prime}}{\sigma_{0}{ }^{\prime}}\right)^{2}=0$

なお， $\sigma_{n}{ }^{\prime}$ ならびに式 (9), 式 (10) の誘導に関しては, Appendix 1 に示した.

式 (6) 〜式 (10) を用いて, 本泥岩に対する $\theta_{0}, \theta_{1}, \theta_{2}$ と拘束圧 $\sigma_{3}{ }^{\prime}$ の関係を求めると, 図一15 が得られる. 図中，実線は $\theta_{1}$ と $\theta_{2}$ を，一点鎖線は $\theta_{0}$ を表わして いる. また 表一4 には, 拘束圧 $1 \mathrm{kgf} / \mathrm{cm}^{2}\left(9.8 \times 10^{-2}\right.$ $\mathrm{MPa})$ の間隔で $\theta_{0}, \theta_{1}, \theta_{2}$ の值を与えている. なお式 （9），(10）の解析には，ニュートン法を適用した.

図より，拘束圧に依存して既存の切断面に沿うすべり 破壊を生ずる切断面の角度の範囲は変化し，高くなるに 従ってその範囲が狭くなるのがわかる. 先の報告ならび に今回の実験より, 遷移応力状態に至ると, 供試体の変 
形はすべて樽型となり, 变形挙動に対する切断面の影響 が消滅することは明らかである．よって図中の 3 本の曲 線は, 遷移応力に近くなるに従って1本の曲線に漸近す るのが理想である. 求めた曲線が $\sigma_{3}{ }^{\prime}=16.7 \mathrm{kgf} / \mathrm{cm}^{2}$ $(1.6 \mathrm{MPa})$ において， $\theta_{0}, \theta_{1}$ と $\theta_{2}$ との間に約 $10^{\circ}$ の開 きがあるのは，破壊規準を式（4)，(5) のべき関数型で 定義したため, 遷移応力状態すなわち式 (4) と式 (5) の交点において, 最大強度曲線が不連続になるからであ る.

次に実験值との比較を行う。図一15には，各供試体 について, 新しく破断面の生じたものに対しては白丸， 既存の切断面に沿ってすべり破断を生じたものに対して は黒丸で結果を示した．特に， $\theta_{1}, \theta_{2}$ 曲線の境界付近に 着目すると， $\theta_{2}$ に関してはほぼ正確に実験結果を評価 している. 一方, $\theta_{1}$ は低拘束圧下，すなわち $\sigma_{3}{ }^{\prime}=1$ $\mathrm{kgf} / \mathrm{cm}^{2}\left(9.8 \times 10^{-2} \mathrm{MPa}\right), 3 \mathrm{kgf} / \mathrm{cm}^{2}\left(2.7 \times 10^{-1} \mathrm{MPa}\right)$ に対しては実験結果とよい一致を示すが, 拘束圧が高く なる $6 \mathrm{kgf} / \mathrm{cm}^{2}\left(5.4 \times 10^{-1} \mathrm{MPa}\right), 10 \mathrm{kgf} / \mathrm{cm}^{2}(9.8 \times$ $\left.10^{-1} \mathrm{MPa}\right)$ の場合には，実験結果よりもやや小さい值 を与える傾向にある.これらより判断すれば，真の $\theta_{1}$ の值, すなわち切断面に沿うすべり破壊を生ずる角度の 下限值は， $\sigma_{3}{ }^{\prime}=6 \mathrm{kgf} / \mathrm{cm}^{2}\left(5.4 \times 10^{-1} \mathrm{MPa}\right)$ では, $45^{\circ}$ と $52.5^{\circ}$ の間にあるはずである. なお， $\sigma_{3}{ }^{\prime}=10 \mathrm{kgf} / \mathrm{cm}^{2}$ $\left(9.8 \times 10^{-1} \mathrm{MPa}\right)$ においては， $\theta=52.5^{\circ}$ 亿対する破壊形 態が，切断面に沿ったすべり破壊のみならず，新たに破 断面を生じていたことを考えれば，ほぼ $52.5^{\circ}$ が下限值 であろう．したがって式 (7) で求まる $\theta_{1}$ の值は，す心゙ り破壊を生じる危険性という見地に立てば，拘束圧が高 くなるに従って安全側の值を与えることになっている. しかしながら，本泥岩の場合 $\sigma_{3}{ }^{\prime}=10 \mathrm{kgf} / \mathrm{cm}^{2}(9.8 \times$ $\left.10^{-1} \mathrm{MPa}\right)$ に至ると，破壊形態の違いがせ几断強度に それほど大きな差異を与えておらず, 実際の軟岩盤でも 不連続面の影響が問題となるのは, 特に低拘束圧状態で ある.すなわち低拘束圧において， $\theta_{1}$ は実験結果をよく 評価しているから，式（7)，（8）は，破壞規準式 (4), （5）の補足規準として適用することが可能であると考え られる. 特に $\sigma_{3}{ }^{\prime}=0 \mathrm{kgf} / \mathrm{cm}^{2}(0 \mathrm{MPa})$ のときの $\theta$ の範 囲は，不連続面に沿ったすべり破壊に対する最も安全側 の範囲を与えてくれることになる.

図一16 は，新たに破断面を生じ破壊した供試体につ いて，その破断面の角度を示した。こちらは明らかに $\theta_{0}$ の值よりも大きな角度となる傾向がある.

したがって, より正確な $\theta_{1}, \theta_{2}$ ならびに $\theta_{0}$ 曲線を得 るためには，式（4)，(5) の破壊規準からの再検討が必 要となってくる. すなわち, 前述の不連続点をいかに補 正するか，あるいはまったく新しい破壊規準を導入すべ きかは, 残された課題といえる.

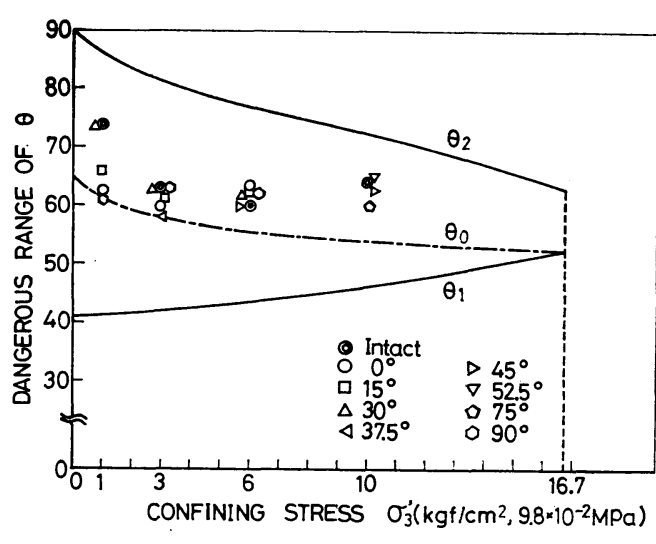

\section{図一16 新たな破断面を生ずる場合の破断面の 角度と拘束圧の関係}

\section{（6）一般応力状態における破壊規準}

以上より，不連続面を有する軟岩の破壊規準を， $\sigma^{\prime}$ 上 $\tau$ 間の関係をもとに求めた.しかし, 一般に地盤材料の破 壊規準は, 平均応力 $\left(\frac{\sigma_{1}{ }^{\prime}+\sigma_{3}{ }^{\prime}}{2}\right)$ と軸差応力 $\left(\frac{\sigma_{1}-\sigma_{3}}{2}\right)$ の関係式で表わすことが多い，そこで，式 (4)，(5)の 破壊規準を変換して， $\sigma_{n}{ }^{\prime}=\frac{\sigma_{1}{ }^{\prime}+\sigma_{3}{ }^{\prime}}{2}$ Ł $q / 2=\frac{\sigma_{1}-\sigma_{3}}{2}$ 上 の関係式として求めると, 遷移応力以下の㐫力状態に対 する破壊規準は次のように得られる.

（1）既存の切断面に関係なく新たに角度 $\theta_{0}$ の破断 面が生じる場合

(i) 最大強度

$$
\left(\frac{q}{2 \sigma_{n 0}{ }^{\prime}} \sin 2 \theta_{0}\right)^{1 / \beta P}=\alpha_{P}\left(\frac{\sigma_{n}{ }^{\prime}}{\sigma_{n 0}{ }^{\prime}}+\frac{q}{2 \sigma_{n 0}{ }^{\prime}} \cos 2 \theta_{0}\right)
$$

(ii） 残留強度

$$
\left(\frac{q}{2 \sigma_{n 0^{\prime}}} \sin 2 \theta_{0}\right)^{1 / \beta_{R}}=\alpha_{R}\left(\frac{\sigma_{n}{ }^{\prime}}{\sigma_{n 0}{ }^{\prime}}+\frac{q}{2 \sigma_{n 0}{ }^{\prime}} \cos 2 \theta_{0}\right)
$$

（2）角度 $\theta$ の切断面に沿ってすべり破壊が生じる 場合

最大強度=残留強度

$$
\left(\frac{q}{2 \sigma_{n 0}{ }^{\prime}} \sin 2 \theta_{0}\right)^{1 / \beta_{R}}=\alpha_{R}\left(\frac{\sigma_{n}{ }^{\prime}}{\sigma_{n 0}{ }^{\prime}}+\frac{q}{2 \sigma_{n 0}{ }^{\prime}} \cos 2 \theta\right)
$$

ここに, $\sigma^{\prime}{ }_{n}$ は単位応力 $=1 \mathrm{kgf} / \mathrm{cm}^{2}\left(9.8 \times 10^{-2} \mathrm{MPa}\right)$ で ある. また同時に, 式 (6)〜 (8) で与えられる拘束圧 $\sigma_{3}{ }^{\prime}$ と角度 $\theta_{0}, \theta_{1}, \theta_{2}$ との間の関係式を, 平均応力: $\sigma_{n}{ }^{\prime}=$ $\frac{\sigma_{1}{ }^{\prime}+\sigma_{3}{ }^{\prime}}{2}$ と $\theta_{0}, \theta_{1}, \theta_{2}$ との関倸式に変換すると, 次式 のようになる.

$$
\theta_{0}=\frac{1}{2} \sin ^{-1}\left(\frac{\alpha_{P} \sigma_{P}{ }^{\prime} \beta_{P}}{\sigma_{3}{ }^{\prime}-\sigma_{n}{ }^{\prime}}\right)=\frac{1}{2} \sin ^{-1}\left(\frac{\alpha_{P} \sigma_{P}{ }^{\prime} \beta_{P}}{f\left(\sigma_{n}{ }^{\prime}\right)-\sigma_{n}{ }^{\prime}}\right)
$$




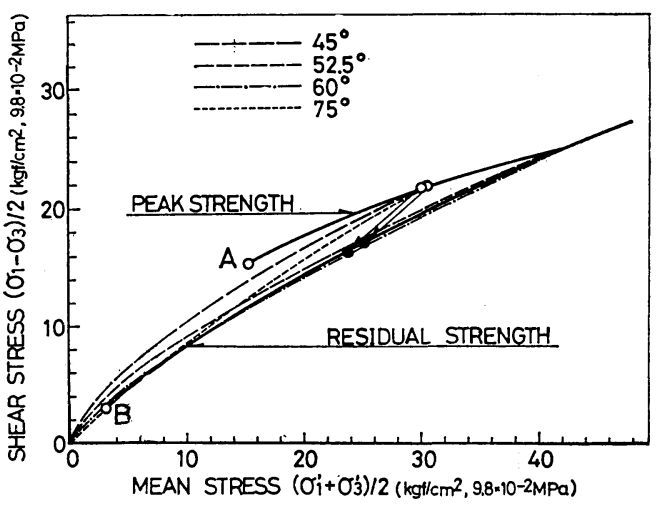

図一17 切断面を有する軟岩の最大強度, 残留強度

$$
\left(\frac{\sigma_{1}{ }^{\prime}+\sigma_{3}{ }^{\prime}}{2} \sim \frac{\sigma_{1}-\sigma_{3}}{2} \text { 関係 }\right)
$$$$
\theta_{1}=\frac{1}{2} \sin ^{-1}\left(\frac{\alpha_{R} \sigma_{R_{1}}{ }^{\prime} \beta_{R}}{{\sigma_{3}{ }^{\prime}-\sigma_{n}{ }^{\prime}}^{\prime}}\right)=\frac{1}{2} \sin ^{-1}\left(\frac{\alpha_{R} \sigma_{R_{1}}{ }^{\prime} \beta_{R}}{f\left(\sigma_{n}{ }^{\prime}\right)-\sigma_{n}{ }^{\prime}}\right)
$$

$\theta_{2}=\frac{1}{2} \sin ^{-1}\left(\frac{\alpha_{R} \sigma_{R_{2}}{ }^{\prime} \beta_{R}}{\sigma_{3}{ }^{\prime}-\sigma_{n}{ }^{\prime}}\right)=\frac{1}{2} \sin ^{-1}\left(\frac{\alpha_{R} \sigma_{R_{2}}{ }^{\prime} \beta_{R}}{f\left(\sigma_{n}{ }^{\prime}\right)-\sigma_{n}{ }^{\prime}}\right)$

式中の $\sigma_{P}{ }^{\prime}, \sigma_{3}{ }^{\prime}=f\left(\sigma_{n}{ }^{\prime}\right)$ ならびに $\sigma_{R_{1}}, \sigma_{R_{2}}$ の值は, $\sigma_{n}{ }^{\prime}$ によって決定されるが, その詳細については Appendix 2 に示した.

また式 (11)，(12）中の $\theta_{0}$ は, 式 (6)' に対応しており, 平均応力 $\sigma_{n}{ }^{\prime}$ に依存して変化する.

図一17 は, 新しく求まった破壊規準に, 本実験に用 いた泥岩の強度定数を代入して得られた曲線である.殏 中太い実線が式 (11), 式 (12) の最大強度曲線, 残留強 度曲線であり, 式 (13) に関しては， $\theta=45^{\circ}, 52.5^{\circ}, 60^{\circ}$, $75^{\circ}$ に対する曲線を与えている. したがって $\theta=45^{\circ}, 75^{\circ}$ の切断面を有する供試体のように, 平均応力 $\sigma_{n}{ }^{\prime}$ の大小 によって破壊形態が異なる場合には, 破壊規準は, 切断 面に沿ったすべり破壊を生ずる間は式（13）に，新たな 破断面を生じる場合は式 (11)，(12) に従うことになる. また，このように破壊規準が変化するときの境界の強度 は，式 (11) と式 (13) の交点で与えられる.

次に変換された式 $(7)^{\prime}$ と式 $(8)^{\prime}$ による $\sigma_{n}{ }^{\prime}$ と $\theta_{1}$, $\theta_{2}$ の関係を 図一18 に示す. 図より平均応力 $\sigma_{n}{ }^{\prime}$ が決定 されれば，そのときの $\theta_{1}, \theta_{2}$ すなわちす心゙り破壊を生 ずる角度の範囲が求まる. また逆に任意の切断面の角度 $\theta$ に対して，破壊規準が式（13）から式（11），(12）に 移行するときの $\sigma_{n}{ }^{\prime}$ の值を決定することができる.

このように，破壊規準が不連続となるのは，すべり破 壞を生じる可能性のある場合で, その角度の範囲は図一 18 の $\sigma_{n}{ }^{\prime}=15.3 \mathrm{kgf} / \mathrm{cm}^{2}(1.5 \mathrm{MPa})$ (図一15 では $\sigma_{3}{ }^{\prime}=$ $\left.0 \mathrm{kgf} / \mathrm{cm}^{2}(0 \mathrm{MPa})\right)$ のときの $\theta_{1}, \theta_{2}$ の值で求まる. 本 実験に用いた泥岩の場合は， $40.9^{\circ}<\theta<90.0^{\circ}$ となる.

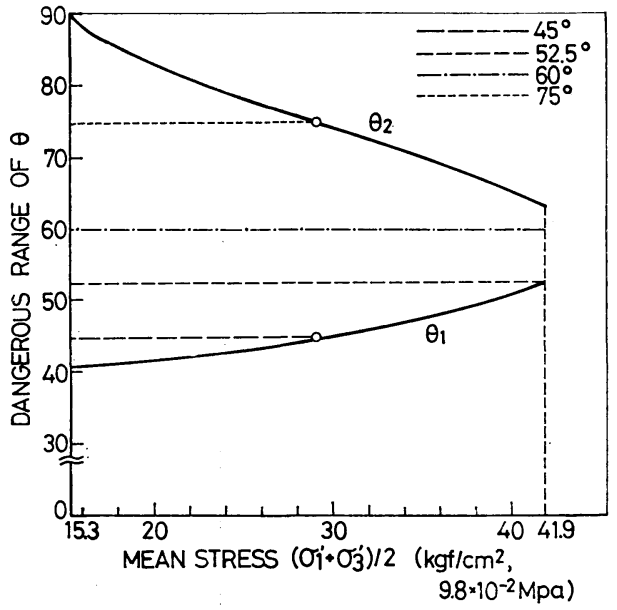

図一18 すべり破壊を生ずる切断面の角度と平均応力の関係

したがって切断面の角度がその角度の範囲外にある上 き，破壊規準は常に式（11）および式（12）で与えられ ることになる。

なお 図一17 中の式 (11), 式 (12) で表わされる最大 強度曲線, 残留強度曲線上の $\bigcirc$ 印で示す 2 点 $\mathrm{A}, \mathrm{B}$ は, 一軸圧縮強度 $\left(\sigma_{3}{ }^{\prime}=0 \mathrm{kgf} / \mathrm{cm}^{2}(0 \mathrm{MPa})\right)$ 意味してい る.

先の報告では，不連続面を有する軟岩の破壊規準が両 対数紙上で直線になる, といら仮定のもとで議論を行っ てきた，そこで式（11）（13）で表わされる破壊規準を 両対数紙上に求め直し，同時に実際に得られた実験值を 与えたものを図一19 に示す. 図中実線がおのおのの不 連続面の角度に対する破壊規準であり，点線は式 (13) が破壊規準である場合の式（11），(12）の位置を示した ものである. 式 (13) に対応する実験值については, 最 大強度＝残留強度であるゆえ黒印で，また式 (11)，(12) に対応するものについては, 最大強度を白印, 残留強度 を黒印で示した，図より，最大強度に多少のばらつきが あるものの，実験值がほぼ強度曲線上に一致しているの がわかる. なお式 (13) における $\theta=45^{\circ}$ の場合の破壞 規準のみが両対数紙上で直線となり，あと法す心゙てやや 上にロの曲線となる。

また 図一20には 図一19 の破壊規準のみをまとめて 示した. 図より式 (13) における $60^{\circ}, 75^{\circ}$ の曲線が, 若 干式 (12) の残留強度曲線の下側にくる部分があるが, ほぼ式 (11)，(12）の最大強度曲線, 残留強度曲線の間 に，他の強度曲線が位置しているのがわかる．このこと は, 先に提起した図一1の考え方, 寸なわち岩盤の強度 は岩石の最大強度を上限值に, 残留強度を下限值として その間に位置する, といらことの妥当性を裏付けるここ になる。 

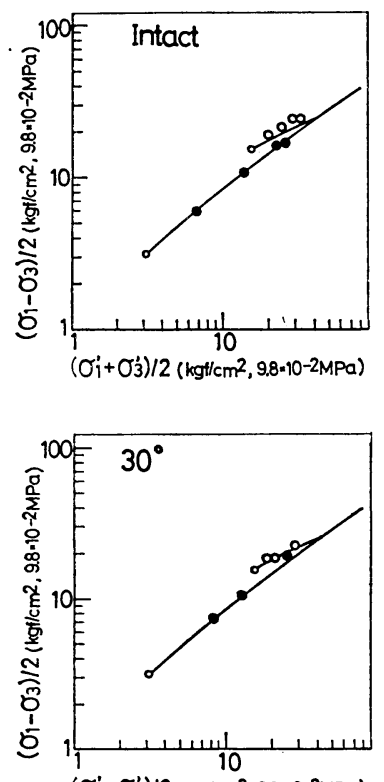

$\left(\sigma_{i}^{\prime}+\sigma_{3}^{\prime}\right) / 2\left(\mathrm{kgt}^{\mathrm{f}} / \mathrm{cm} \mathrm{m}^{2}, 9.8 \times 10-2 \mathrm{MPa}\right)$

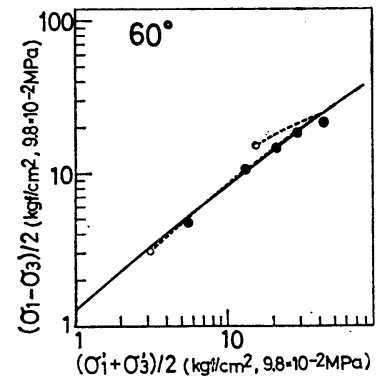

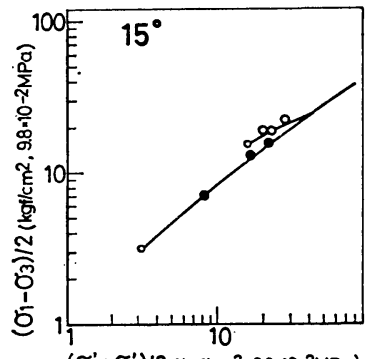

$\left(\sigma_{i}^{\prime}+\sigma_{3}^{\prime}\right) / 2\left(\mathrm{kgt}^{\prime} / \mathrm{cm}^{2}, 9,8 \times 10-2 \mathrm{MPa}\right)$

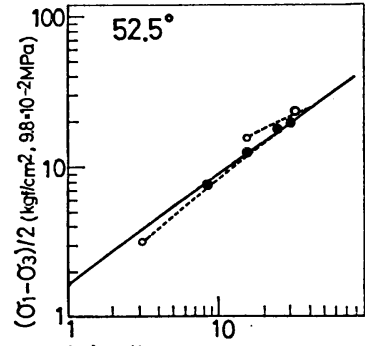

$\left(\sigma_{i}^{\prime}+\sigma_{3}^{\prime}\right) / 2\left(\mathrm{kgt}^{\prime} / \mathrm{cm}^{2}, 9.8 \times 10-2 \mathrm{MPa}\right)$

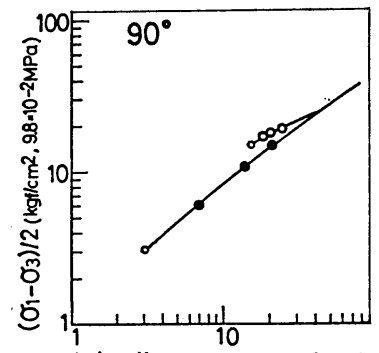

$\left(\sigma_{i}^{\prime}+\sigma_{3}^{\prime}\right) / 2\left(\mathrm{~kg}^{\prime} / \mathrm{cm}^{2}, 9.8-10-2 \mathrm{MPa}\right)$

図一19実験結果と理論値との比較

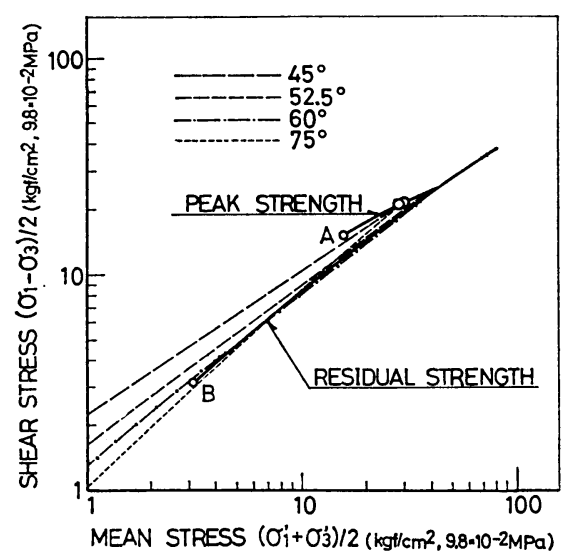

図一20 最大強度, 残留強度の両対数表示

$\left(\frac{\sigma_{1}{ }^{\prime}+\sigma_{3}{ }^{\prime}}{2} \sim \frac{\sigma_{1}-\sigma_{3}}{2}\right.$ 関係)

\section{（7）破壊時の体積変化亡応力の関係}

足立・小川 ${ }^{6)}$ は, 軟岩（大谷石）の最大ならびに残留
強度に対する破壊規準は, 単に応力間の関係のみでは不 十分で応力と体積ひずみの間に成立する関倸も同時に規 定する必要があることを明らかにしている。

すでに論じたように, 切断面が存在していても, その 面に無関係に新たな破断面を生じたものについては, そ の力学特性は Intact rock となんら変わりのないことが 明らかである。

足立・小川による大谷石の破壊時の応力と体積ひずみ に対する破壊規準は最大強度, 残留強度とも遷移応力を 境にして与えられていたが，泥岩を試料とした本実験は 異なる結果を示している. 図一21 は Intact rock なら びに新しく破断面を生じたものについての体積ひずみ $v(\%)$ と平均有効応力 $\sigma_{m}{ }^{\prime}\left(\mathrm{kgf} / \mathrm{cm}^{2}, 9.8 \times 10^{-2} \mathrm{MPa}\right)$ 間 の関係を, 最大強度時を白印, 残留強度時を黒印で示し たものである.な打図中の一点鎖線は等方圧密曲線であ る. 本研究では, CD-20, $60^{\circ}$ を除いては, 遷移応力以 下での実験であったが, 最大強度時の関係は遷移応力以 下では圧密曲線によって表わされる. 一方, 残留強度に 


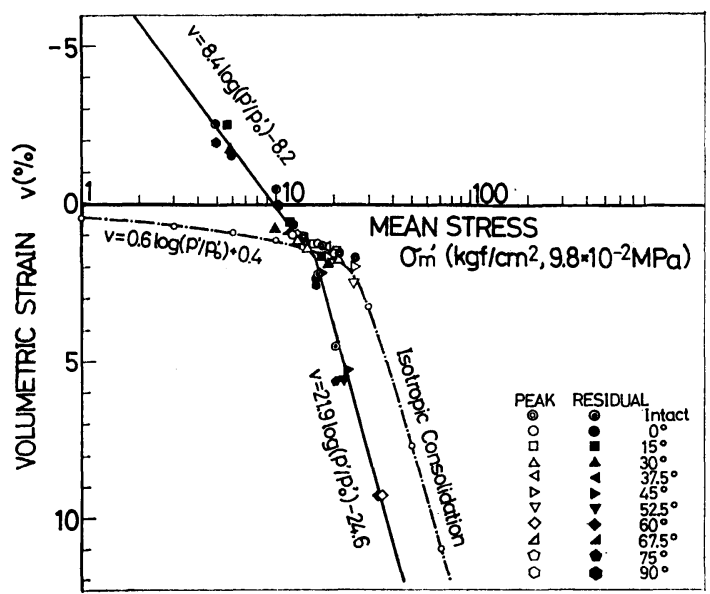

図 21 新たに破断面を生じる場合の切断面を有する 供試体の最大ならびに残留強度時の平均有効 応力と体積ひずみ関係

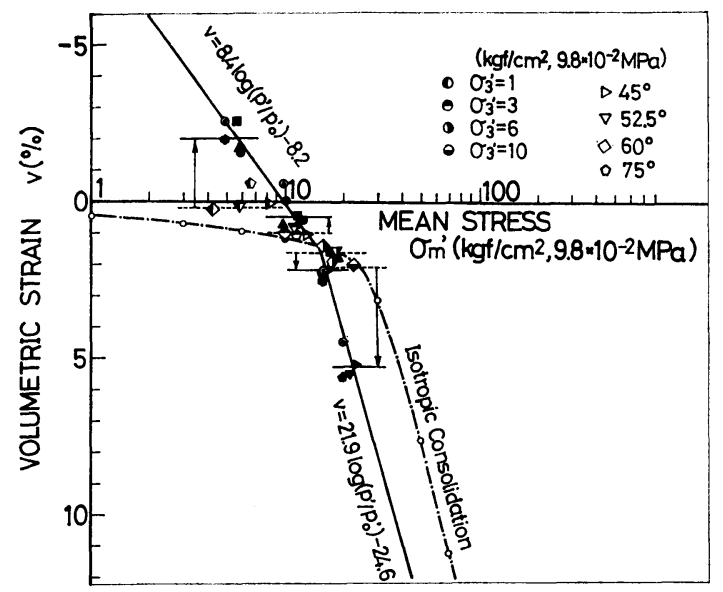

図一22 既存の切断面に沿うすべり破壊を生じる場合の 残留強度時の平均有効応力と体積ひずみ関係

関しては, 遷移応力を境にしてではなく, 圧密曲線の上 下で異なる勾配をもった 2 本の直線関係となる.

上述した大谷石との相違は, 構造骨格, セメンテーシ ョンなどにおける差異に起因するものと考えられるが, この点に関しては今後詳細に検討する必要がある. な お，図中には，それぞれの関係を直線としたときの破壊 規準を示した.

次に, 不連続面に沿ってすべり破壊を生じたものにつ いての体積ひずみ〜応力関係を検討してみる. 図一22 には, すべり破壊時の残留状態における体積ひずみ〜応 力関係と, 比較のために 図一21 の残留強度時の同関係 を示した.

図より, 膨張側, 圧縮側ともに不連続面に沿ってすべ っている場合は, 体積変化の割合が少ないことが明らか
であるせせん断変形が不連続面に沿った非常に局部的な 変形であるため, せん断のごく初期からせん断中の体積 変化がその部分にしか発生しなかったからであろう。

また等拘束圧の結果に関して体積ひずみを比較する と, $\sigma_{m}{ }^{\prime}$ ならびに切断面の角度に関係なく, 体積ひずみ はほぼ等しい量であることがわかる. CD-1 に関して は，75の值がやや他のものより膨張傾向があるが，こ れは 3.（2）でも論じたように，切断面が供試体の上下 端を切るため, せん断の初期にすべり変形が制約され, 局部的なせん断破壊を生じたからであろら. 特に低拘束 圧ではその影響が大きく，そのために正のダイレイタン シー効果を示したものと考えられる.

したがって，各拘束圧ごとにそれぞれ新たに破壊した もの，切断面に沿ってすべり破壊を生じたものについて の体積ひずみの平均值を求めると, その差がすなわち破 壊形態の相違による体積変化量の差となる. 図一22 に は, 実線で新たに破壊したものの平均值を, 点線で切断 面に沿ってすべり破壊を生じたものの平均值をあわせて 示している. 切断面に沿ってすべっている状態も，新た な破断面を生じてそれに沿ってすべっている状態も, 最 終的にはその変形状態は, 有効応力も体積も変化しない いわゆる残留応力状態であると考えられる.よって図中 の矢印で表わされる量が，各拘束圧において，破断面が 生じることによって発生するダイレタンシー量と考える ことができる.

以上, 切断面を人工的に与えた供試体の室内三軸試験 の結果をもとに, 不連続面を有する軟岩の破壊規準を求 めた. 破壊規準を確定するには, 強度定数 $\alpha_{P}, \beta_{P}, \alpha_{R}$, $\beta_{R}$ を実験より決定する必要がある. これらの強度定数 は, 対象とする軟岩固有の材料定数であるから, 結果的 には本実験のように切断面を有する供試体を用いなくて も，通常の岩石試験で決定することができる.このよう に, 比較的簡単に行える室内岩石試験によって, 岩盤の 強度を推定することが可能となる. 結局不連続面を有す る軟岩の破壊規準としては, 直接的に不連続面上の応力 を問題とする場合は式 (4)，(5) を，一般的な応力状態 を論ずるときは式 (11)〜 (13) を, さらにそれらの補足 規準として，それぞれ式 (7)，(8) および式 $(7)^{\prime},(8)^{\prime}$ を 用いるのが, 実際の軟岩盤の解析に適用するうえで, 最 も有効であると考えられる.

\section{4. 結 論}

層理，節理などの地質分離面が，軟岩よりなる岩盤に 与える影響を解明する 1 つの方法として, 種々の角度の 切断面を人工的に与えた供試体を用いて三軸試験を行っ た. その結果得られた知見をまとめると以下のようにな 
る.

（1）遷移応力以下においては，切断面を有する供試 体の破壊形態は次の 2 つ大別される. すなわち切断面 に無関倸に新たな破断面が生じる場合と, 既存の切断面 に沿ったすべり破壊を生じる場合である.

（2）切断面に無関係に新たな破断面が生じる場合の 力学挙動は, Intact rock のそれと同様な挙動を示す. また切断面に沿ったすべり破壊を生じる場合のせん断強 度は, Intact rock の強度より小さくなり, 切断面の角 度によって変化する。

（3）切断面に沿ったすべり破壊を生じる角度 $\theta$ の範 囲は, 拘束圧または平均主応力によって変化し, その範 囲は式 (7)，(8) もしくは式 (7)'，(8)'により与えられ， $\theta_{1} \leqq \theta \leqq \theta_{2}$ である.

（4）遷移応力に近づくに従って，すべり破壊を生ず る角度 $\theta$ の範囲汁狭くなって, 破壊形態も樽型を示すよ らになり, 既存の切断面の力学挙動に及ぼす影響は次第 に消滅する。

（5）せん断初期の応力〜ひずみ関係より求まるせん 断弹性係数 $G$, 体積弾性係数 $K$ は双方ともにすべり破 壊を生じる場合, それらの值は小さくなり，60 あたり で最小值をとる.

（6）切断面を有する軟岩の最大強度, 残留強度間に 成り立つ関係を, 切断面もしくは破断面上に作用する垂 直応力 $\sigma^{\prime}$ とせん断応力 $\tau$ で表わすと, 切断面の有無, 角度にかかわらず式 (4), 式 (5) で表わされるべき関数 型の曲線となる. またその強度定数 : $\alpha_{P}, \beta_{P}, \alpha_{R}, \beta_{R}$ は, 対象とする軟岩固有の材料定数である.

（7）不連続面を有する軟岩の破壊規淮は，切断面も しくは破断面上の応力を 問題とするときは式 (4)，(5) により, 岩盤の強度といら観点より解析する場合は式 (11)〜 (13) により，さらにそれぞれ式 (7)，(8), 式 (7)'，(8)' をその補足規準として与えられる.

（）切断面に沿うすべり破壊を生じた岩石の体積変 化量は, 圧縮側, 膨張側とも Intact な材料と比べて小 さく, 同じ拘束圧のものについては, 切断面の角度, 残 留状態での平均主応力に影響されずほぼ一定值をとる.

本研究は京都大学防災研究所地盤災害部門で行ったも のであり， 日頃ご指導をいただいている 柴田 徹教授 に厚くお礼を申し上げる次第である. なお, 本研究に対 ᄂ昭和 54 年度文部省科学研究費 (一般研究C) の交付 を受けたことを付記し，謝意を表する.

\section{Appendix 1 式 (9)，(10）の導入}

遷移応力以下の最大強度に関する破壊規準は次式で与 えられた。 $\left(\tau / \sigma_{0}{ }^{\prime}\right)$ peak $=\alpha_{P}\left(\sigma^{\prime} / \sigma_{0}{ }^{\prime}\right)^{\beta_{P}}$ (i $)=(4)$

また拘束圧 $\sigma_{3}{ }^{\prime}$, 軸圧 $\sigma_{1}{ }^{\prime}$ のときのモールの応力円は次 式で与えられる.

$$
\left(\frac{\sigma^{\prime}}{\sigma_{0}{ }^{\prime}}-\frac{\sigma_{1}{ }^{\prime}+\sigma_{3}{ }^{\prime}}{2 \sigma_{0}{ }^{\prime}}\right)^{2}+\left(\frac{\tau}{\sigma_{0}{ }^{\prime}}\right)^{2}=\left(\frac{\sigma_{1}-\sigma_{3}}{2 \sigma_{0}{ }^{\prime}}\right)^{2}
$$

式 (i)，(ii) をそれぞれ $\sigma^{\prime}$ で微分し， $d \tau / d \sigma^{\prime}$ を求める と, 式 (i)より,

$d \tau / d \sigma^{\prime}=\alpha_{P} \beta_{P}\left(\sigma^{\prime} / \sigma_{0}{ }^{\prime}\right)^{\beta_{P}-1}$

式(ii)より,

$$
d \tau / d \sigma^{\prime}=-\left(\frac{\sigma^{\prime}}{\sigma_{0}{ }^{\prime}}-\frac{\sigma_{1}{ }^{\prime}+\sigma_{3}{ }^{\prime}}{2 \sigma_{0}{ }^{\prime}}\right) /\left(\frac{\tau}{\sigma_{0}{ }^{\prime}}\right)
$$

(i), (ii) が, A 点 $\left(\sigma_{P}{ }^{\prime}, \tau_{P}\right)$ で接するとき, $\mathrm{A}$ 点での微 分係数は等しいゆえ, 式 (iii), (iv) より,

$$
\alpha_{P} \beta_{P}\left(\frac{\sigma_{P}{ }^{\prime}}{\sigma_{0}{ }^{\prime}}\right)^{\beta_{P}-1}=-\left(\frac{\sigma_{P}{ }^{\prime}}{\sigma_{0}{ }^{\prime}}-\frac{\sigma_{1}{ }^{\prime}+\sigma_{3}{ }^{\prime}}{2 \sigma_{0}{ }^{\prime}}\right) /\left(\frac{\tau_{P}}{\sigma_{0}{ }^{\prime}}\right)
$$

式（v）を変形し, $\left(\frac{\tau_{P}}{\sigma_{0}{ }^{\prime}}\right)=\alpha_{P}\left(\frac{\sigma_{P}{ }^{\prime}}{\sigma_{0}{ }^{\prime}}\right)^{\beta_{P}}$ を代入すれば,

$$
\frac{\sigma_{1}{ }^{\prime}+\sigma_{3}{ }^{\prime}}{2 \sigma_{0}{ }^{\prime}}\left(=\frac{\sigma_{n}{ }^{\prime}}{\sigma_{0}{ }^{\prime}}\right)=\alpha_{P}{ }^{2} \beta_{P}\left(\frac{\sigma_{P}{ }^{\prime}}{\sigma_{0}{ }^{\prime}}\right)^{2 \beta_{P}-1}+\left(\frac{\sigma_{P}{ }^{\prime}}{\sigma_{0}{ }^{\prime}}\right)
$$

また式（vi）の両辺より $\left(\frac{\sigma_{3}{ }^{\prime}}{\sigma_{0}{ }^{\prime}}\right)$ を引けば，

$$
\begin{aligned}
& \frac{\sigma_{1}-\sigma_{3}}{2 \sigma_{0}{ }^{\prime}}\left(=\frac{q}{2 \sigma_{0}^{\prime}}\right)=\alpha P^{2} \beta_{P}\left(\frac{\sigma_{P^{\prime}}}{\sigma_{0}^{\prime}}\right)^{2 \beta_{P}-1} \\
& +\left(\frac{\sigma_{P^{\prime}}}{\sigma_{0}^{\prime}}\right)-\left(\frac{\sigma_{3}^{\prime}}{\sigma_{0}^{\prime}}\right)
\end{aligned}
$$

式 (vi)，(vii) を式（ii) に代入し，さらに式（i）を代 入すれば, 式 (9) が導入される. よって $\sigma_{3}{ }^{\prime}$ を与えれ ば, 接点 $\mathrm{A}$ の垂直応力成分 $\sigma_{P}{ }^{\prime}$ は, 次式を数值解析す ることによって求まる.

$$
\begin{gathered}
\alpha_{P}{ }^{2}\left(2 \beta_{P}-1\right)\left(\frac{\sigma_{P}{ }^{\prime}}{\sigma_{0}{ }^{\prime}}\right)^{2 \beta_{P}}-2 \alpha_{P}{ }^{2} \beta_{P}\left(\frac{\sigma_{3}{ }^{\prime}}{\sigma_{0}{ }^{\prime}}\right)\left(\frac{\sigma_{P}{ }^{\prime}}{\sigma_{0}{ }^{\prime}}\right)^{2 \beta_{P}-1} \\
+\left(\frac{\sigma_{P}{ }^{\prime}}{\sigma_{0}{ }^{\prime}}\right)^{2}-2\left(\frac{\sigma_{3}{ }^{\prime}}{\sigma_{0}{ }^{\prime}}\right)\left(\frac{\sigma_{P}{ }^{\prime}}{\sigma_{0}{ }^{\prime}}\right)+\left(\frac{\sigma_{3}{ }^{\prime}}{\sigma_{0}{ }^{\prime}}\right)^{2}=0
\end{gathered}
$$

また，残留強度に関する破壊規準は次式で与えられ た.

$$
\left(\tau / \sigma_{0}{ }^{\prime}\right)_{\text {residual }}=\alpha_{R}\left(\sigma^{\prime} / \sigma_{0}{ }^{\prime}\right)^{\beta_{R}} \cdots \cdots \cdot(\text { viii })=(5)
$$

2 点, $\mathrm{B}\left(\sigma_{R_{1}}, \tau_{R_{1}}\right), \mathrm{C}\left(\sigma_{R_{2}}, \tau_{R_{2}}\right)$ は, (ii) と (viii) の 交点であるから, 式 (viii) を式（ii）に代入して,

$$
\left(\frac{\sigma_{R}{ }^{\prime}}{\sigma_{0}{ }^{\prime}}-\frac{\sigma_{1}{ }^{\prime}+\sigma_{3}{ }^{\prime}}{2 \sigma_{0}{ }^{\prime}}\right)^{2}+\left[\alpha_{R}\left(\frac{\sigma_{R}{ }^{\prime}}{\sigma_{0}{ }^{\prime}}\right)^{\beta_{R}}\right]^{2}=\left(\frac{\sigma_{1}-\sigma_{3}}{2 \sigma_{0}{ }^{\prime}}\right)^{2}
$$

ここで, $\frac{\sigma_{1}{ }^{\prime}+\sigma_{3}{ }^{\prime}}{2 \sigma_{0}{ }^{\prime}}=\frac{\sigma_{n}{ }^{\prime}}{\sigma_{0}{ }^{\prime}}, \frac{\sigma_{1}-\sigma_{3}}{2 \sigma_{0}{ }^{\prime}}=\frac{\sigma_{n}{ }^{\prime}}{\sigma_{0}{ }^{\prime}}-\frac{\sigma_{3}{ }^{\prime}}{\sigma_{0}{ }^{\prime}}$ として式

（ix）を整理すれば, 式（10）が導入される.

$$
\begin{gathered}
\alpha_{R}{ }^{2}\left(\frac{\sigma_{R}{ }^{\prime}}{\sigma_{0}{ }^{\prime}}\right)^{2 \beta_{R}}+\left(\frac{\sigma_{R^{\prime}}}{\sigma_{0}^{\prime}}\right)^{2}-2\left(\frac{\sigma_{n}{ }^{\prime}}{\sigma_{0}{ }^{\prime}}\right)\left(\frac{\sigma_{R^{\prime}}}{\sigma_{0}{ }^{\prime}}\right) \\
\quad+2\left(\frac{\sigma_{n}{ }^{\prime}}{\sigma_{0}{ }^{\prime}}\right)\left(\frac{\sigma_{3}{ }^{\prime}}{\sigma_{0}^{\prime}}\right)-\left(\frac{\sigma_{3}{ }^{\prime}}{\sigma_{0}^{\prime}}\right)^{2}=0 \cdots \cdots
\end{gathered}
$$


式中 $\sigma_{n}{ }^{\prime}$ の值は, 式 (vi) で求められる.よって, $\sigma_{3}{ }^{\prime}$ が 与えられれば, 式 (9) より $\sigma_{P}{ }^{\prime}$ が計算され, さらに式 (vi) によって $\sigma_{n}{ }^{\prime}$ が求まり, 2 交点 $\mathrm{B}, \mathrm{C}$ の垂直応力 成分 $\sigma_{R_{1}}{ }^{\prime}, \sigma_{R_{2}}{ }^{\prime}$ は, 式 (10) を数值解析することによ って決定できる.

\section{Appendix 2}

式中の $\sigma_{P}{ }^{\prime}$ に関しては, 先に示した式（vi）を与えら れた $\sigma_{n}{ }^{\prime}$ について数值解析すれば求まる. これを

$$
\sigma_{P}{ }^{\prime}=f_{1}\left(\sigma_{n}{ }^{\prime}\right) \text { とおく }
$$

またそのときの $\sigma_{3}{ }^{\prime}$ の值は, 式 $(\mathrm{x})$ によって求められ た $\sigma_{P^{\prime}}$ を式 (9) に代入することにより与えられる.こ れを

$$
\sigma_{3}{ }^{\prime}=f_{2}\left(\sigma_{P}{ }^{\prime}\right) \text { とおく }
$$

式 $(\mathrm{x}),(\mathrm{xi})$ より, $\sigma_{3}{ }^{\prime}=f_{2}\left\{f_{1}\left(\sigma_{n}{ }^{\prime}\right)\right\}=f\left(\sigma_{n}{ }^{\prime}\right)$ となり, $\sigma_{3}{ }^{\prime}$ は $\sigma_{n}{ }^{\prime}$ より求められる.

さらに, $\sigma_{R_{1}}{ }^{\prime}, \sigma_{R_{2}}{ }^{\prime}$ に関しては, 式 (10) に $\sigma_{n}{ }^{\prime}$ なら びに上記より求まる $\sigma_{3}{ }^{\prime}$ の值を代入すれば, 数值解析に より決定できる.

\section{参考文 献}

1）足立紀尚・林 正之：軟岩の力学特性に及ぼす不連続面 の影響, 土木学会論文 報告集, No. 305, pp. $97 \sim 110$, 1981.

2) Hobbs, D.W. : A Study of the Behavior of Broken Rock under Triaxial Compression and its Application to Mine Roadways, Int. J. Rock Mech. Minning Sci., Vol. 3, pp. 11 14, 1966.
3) Murrell, S.A.F. : The Effect of Triaxial Stress Systems on the Strength of Rocks at Atmospheric Temperatures, Geophys. J., Vol. 10, No. 3, pp. 231 281, 1966.

4) 赤井浩一.足立紀尚・西 好一：堆積軟岩（多孔質凝灰 岩）の弾・塑性挙動, 士木学会論文報告集, No. 271, pp. 83 95, 1978.

5）堀 正幸：三軸試験結果に及ぼす面積掞よびメンブレン 補正について, 土木学会関西支部年次学術講演会講演概 要, p. III-15, 1978.

6）足立紀尚・小川豊和：堆積軟岩の力学特性と破壊視準, 土木学会論文報告集, No. 295, pp. 51 63, 1980.

7) Okusa, S. : Strength and Earth Pressure of Rock with Weak Planes, Soils and Foundations, Vol. VIII, No. 1, pp. 49 79, 1968.

8) Müller, L. and F. Pacher : Modellversuche zur Klärung der Bruchgefahr, Rock Mechanics and Engineering Geology, Suppl. 2, pp. 7 24, 1965.

9) Einstein, H.H., R.H. Nelson, R.W. Bruhn and R.C. Hirschfeld : Model Studies of Jointed-Rock Behavior, Proc. 11th Symp. on Rock Mech. (AIME), pp. 83 109, 1970.

10) Ladanyi, B. and G. Archambault : Simulation of Shear Behavior of a Jointed Rock Mass, Proc. 11th Symp. on Rock Mech. (AIME), pp. 105 125, 1970.

11) Einstein, H.H. and R.C. Hirschfeld : Model Studies on Mechanics of Jointed Rock, Proc. ASCE, SM 3 , pp. $229 \sim 248,1973$.

12) Bray, J.W. : A Study of Jointed and Fractured Rock, Parts I and II, Rock Mechanics and Engineering Geology, 5, No. 2, 3, 4, pp. $117 \sim 136$, pp. $197 \sim 216$, 1967.

13) John, K.W.: Three Dimentional Stability Analysis of Slopes in Jointed Rock, Proc. Johannesburg Symp. on Rock Mech. South Africa.

(1981.3.19. 受付) 